\title{
Applications of Metals for Bone Regeneration
}

\author{
Kristina Glenske ${ }^{1,+}{ }^{\dagger}$ Phil Donkiewicz ${ }^{2,+}$, Alexander Köwitsch ${ }^{2}$, Nada Milosevic-Oljaca ${ }^{1}$, \\ Patrick Rider ${ }^{2}$, Sven Rofall ${ }^{2}$, Jörg Franke ${ }^{3}$, Ole Jung ${ }^{4}$, Ralf Smeets ${ }^{4}$, Reinhard Schnettler ${ }^{5}$, \\ Sabine Wenisch ${ }^{1, *,+}$ and Mike Barbeck $2,4, *,+$ (ID \\ 1 Clinic of Small Animals, c/o Institute of Veterinary Anatomy, Histology and Embryology, Justus Liebig \\ University of Giessen, D-35392 Giessen, Germany; Kristina.Glenske@vetmed.uni-giessen.de (K.G.); \\ Nada.Milosevic-Oljaca@vetmed.uni-giessen.de (N.M.-O.) \\ 2 Botiss Biomaterials, D-12109 Berlin, Germany; Phil.Donkiewicz@botiss.com (P.D.); \\ alexander.koewitsch@botiss.com (A.K.); patrick.rider@botiss.com (P.R.); Sven.Rofall@botiss.com (S.R.) \\ 3 Clinic for Trauma Surgery and Orthopedics, Elbe Kliniken Stade-Buxtehude, D-21682 Stade, Germany; \\ Joerg.Franke@elbekliniken.de \\ 4 Department of Oral and Maxillofacial Surgery, University Hospital Hamburg- Eppendorf, \\ D-20246 Hamburg, Germany; ol.jung@uke.de (O.J.); r.smeets@uke.de (R.S.) \\ 5 Justus Liebig University of Giessen, 35390 Giessen, Germany; reiner.schnettler@mac.com \\ * Correspondence: Sabine.Wenisch@vetmed.uni-giessen.de (S.W.); mike.barbeck@icloud.com (M.B.); \\ Tel.: +49-641-9938111 (S.W.); +49-176-81022467 (M.B.) \\ † Kristina Glenske and Phil Donkiewicz contributed equally to this work; Sabine Wenisch and Mike Barbeck \\ contributed equally to this work.
}

Received: 5 February 2018; Accepted: 11 March 2018; Published: 12 March 2018

\begin{abstract}
The regeneration of bone tissue is the main purpose of most therapies in dental medicine. For bone regeneration, calcium phosphate ( $\mathrm{CaP}$ )-based substitute materials based on natural (alloand xenografts) and synthetic origins (alloplastic materials) are applied for guiding the regeneration processes. The optimal bone substitute has to act as a substrate for bone ingrowth into a defect, as well as resorb in the time frame needed for complete regeneration up to the condition of restitution ad integrum. In this context, the modes of action of CaP-based substitute materials have been frequently investigated, where it has been shown that such materials strongly influence regenerative processes such as osteoblast growth or differentiation and also osteoclastic resorption due to different physicochemical properties of the materials. However, the material characteristics needed for the required ratio between new bone tissue formation and material degradation has not been found, until now. The addition of different substances such as collagen or growth factors and also of different cell types has already been tested but did not allow for sufficient or prompt application. Moreover, metals or metal ions are used differently as a basis or as supplement for different materials in the field of bone regeneration. Moreover, it has already been shown that different metal ions are integral components of bone tissue, playing functional roles in the physiological cellular environment as well as in the course of bone healing. The present review focuses on frequently used metals as integral parts of materials designed for bone regeneration, with the aim to provide an overview of currently existing knowledge about the effects of metals in the field of bone regeneration.
\end{abstract}

Keywords: metals; dental regeneration; bioactivity; tissue regeneration; bone

\section{Introduction}

The regeneration of bone is of special interest, most notably in dental medicine. For the regeneration of bone tissue of the jaw and also within the sinus cavity, autografts are still the so-called "gold standard" due to their osteoinductive, osteogenic and osteoconductive regenerative capacities [1]. These properties are based on the different components of the transplanted bone tissue: calcified 
bone matrix, different bone cell types, i.e., osteoblasts, osteocytes and osteoclasts, and the connective tissue including the vasculature and, thus, endothelial cells, as well as other, different cell types such as macrophages (so-called "osteomacs") and fibroblasts, amongst others, are components of autografts [2]. Additionally, bone-associated proteins such as members of the bone morphogenetic protein (BMP) family or osteopontin, osteonectin and osteocalcin beside matrix- and cell-related metal ions are integral parts of autografts. An autograft represents a physiologically active transplant, as all of these components allow support of the bone regeneration process after implantation into a defect side [3,4]. However, the application of autografts requires the harvest of healthy bone tissue from another part of the body, i.e., from extraoral locations such as the hip crest or intraoral localizations such as the mandibular ramus. Thus, one of the disadvantages of the application of bony autografts is the second defect side that is created for harvesting of the bone tissue. Besides different complications that could accompany this second surgical intervention, the amount of bone tissue from other locations is often limited and, thus, is not sufficient to fill a bone defect [5].

Beside autografts, a variety of so-called bone substitute materials has been developed within the last decades to overcome the issues with bone autografts. In this context, two main material classes are differentiated: bone substitutes based on "natural" precursors and synthetic materials [6]. The natural-based bone substitute materials are mainly processed from human or animal bone (alloand xenografts). For the manufacturing of allogenic bone substitutes, bone tissue from living donors, i.e., from femoral heads, or of dead donors, is used, while xenografts are mainly processed from bovine bone (or recently porcine bone). Furthermore, different natural materials based on a variety of biopolymers such as silk fibroin, amongst many others, have been analyzed for application as bone substitutes within the last decades $[7,8]$.

Moreover, different synthetic bone substitute materials have been developed, and most of these materials that are clinically applied are based on calcium phosphates such as hydroxyapatite (HAp) or $\beta$ tricalcium-phosphate ( $\beta$-TCP) [9]. Even mixtures of these compounds have been shown to provide good healing results based on the combined degradation behavior. Moreover, a variety of other synthetic materials also combined with techniques such as three-dimensional printing procedures have been tested and have shown to be suitable for bone regeneration [10-12].

However, the regenerative properties of all the afore-mentioned biomaterials are restricted, particular in comparison to autografts as most of the bone substitute materials provide only a basis for osteoconductive bone growth [13]. Until now, no bone substitute material has been developed that features comparable regenerative capacities compared to autografts.

Different strategies have been originated to overcome this issue. A first group of concepts includes synthetic bone substitute materials with controllable material characteristics such as porosity or (nano-) topography [14]. It has been suggested that even these special material properties, which are often stated to mimic the characteristics of the bony extracellular and calcified matrix and, thus, being "biomimetic", allow for induction of bone growth [15]. Interestingly, many publications including in vitro studies and in vivo analyses within ectopic tissues such as the subcutaneous connective tissue, describe osteoinductive properties of especially developed synthetic bone substitute materials [16]. However, the suspected osteoinductive properties of such materials have never been revealed in clinical studies, indicating that such a concept is still not tenable.

A second concept group includes the addition of different biologically active agents such as collagen, hyaluronic acid or osteoinductive molecules, such as members of the bone morphogenetic protein (BMP) family [17-20]. In this context, it has been shown that the combination of synthetic bone substitutes with extracellular matrix proteins, such as collagen, leads to diverse regenerative results. On the one hand, the polymer addition can allow an increase in bony integration behavior, while other results report significantly lower bone growth rates for such a material composition in comparison to the bone substitute material alone [21-24]. In the case of the addition of molecules such as BMPs, other issues have been realized, although a variety of studies has shown their exceptional regenerative properties [25-27]. This results from the facts that the underlying regenerative mechanisms of BMPs 
are not yet understood and possible side effects are not well-known, especially since such molecules are usually administered in non-physiological doses (thousands to millions times the amount normally found in the body) [28]. Additionally, such molecules are still very expensive, although also available as recombinant proteins compared to other bone substitute materials [27]. Furthermore, the effect of the immobilized growth factor also depends on the amount released within a certain timeframe. Hence, the material properties such as porosity play a significant role [29].

A further group of tissue engineering concepts includes the addition of different cell types to bone substitute materials. Most often osteoblasts and their precursor cells are used for such material-cell-combinations, based on the fact that this cell type is mainly involved in bone regeneration by deposition of the organic extracellular matrix and its subsequent mineralization [30]. In this context, mesenchymal stem cells are also of special interest as this cell type represents the earliest cellular step in osteoblastic differentiation [31]. Furthermore, the additions of other cell types that directly or indirectly support the bone growth process have been examined [32]. For example, the influence of different endothelial cell types, such as human dermal microvascular endothelial cells (HDMEC) in mono- or co-culture with bone substitute materials, have been analyzed to provide fast and sufficient vascularization, which is an important factor for bone tissue regeneration [33,34]. Additionally, blood cells or "inflammatory" cells such as cell types of the monocyte/macrophage line have been used to increase the regenerative properties of bone substitutes [35]. This concept is based on the assumption that such cell types express different molecules that are involved in (bone) tissue healing and might induce or at least increase the process of bone regeneration [36-38]. In this context, a broad spectrum of scaffolds combined different blood cells-for example, platelet-rich plasma (PRP) or platelet-rich fibrin (PRF)—obtained by simple centrifugation from freshly drawn venous blood, have also been suggested to increase or even induce bone regeneration [39-41]. The assumption of such concepts is that both the obtained cells and moreover growth factors present within the blood, should stimulate (bone) tissue regeneration [42]. However, all of these tissue engineering concepts did not find their way into the clinic as they are either not applicable in acute surgical situations due to the long time spans needed for cell isolation and co-cultivation with a bone substitute, or their clinical efficacy has still not been proven by scientific analyses such as in the case of PRP or PRF concepts.

A further concept is the application or the combination of different metals or metal ions with bone substitute materials in the field of bone regeneration. Different metal ions are essential components of different tissues, such as calcium phosphates for extracellular calcified bone matrix or integral component of cells or proteins that regulate essential cellular processes, including proliferation and differentiation [43-45]. Together, the different metal ions have functional roles in the physiological cellular environment as well as in the course of bone healing. Thus, the application of metal ions in combination with the above-mentioned bone substitutes or singularly, is of special interest for bone regeneration [46-48]. To provide an overview of the regenerative potential of the different metal ions, the present review summarizes the knowledge about their involvement in cellular processes and the bone healing process, with a further focus on studies that have already analyzed the regenerative potential of bone substitutes, including metals.

\section{Bone Tissue Healing and Approaches for Material-Related Support}

The process of bone tissue healing is based on different factors. Primarily, the bone related cells, i.e., osteoblasts, osteoclasts and their precursors, are involved in this process [49]. In this context, most bone substitute materials allow for the osteoconductive ingrowth of osteoblasts and mesenchymal progenitors acting as a scaffold structure $[50,51]$. Afterwards, osteoblasts produce the extracellular organic bone matrix, which mainly consists of collagen type 1 , and hydroxyapatite is crystallized on the collagen fibrils. Moreover, osteoblasts trigger and promote the crystallization by secretion and expression of various other proteins or receptors such as the receptor activator of NF- $\mathrm{kB}$ ligand (RANKL) and GDF5 [52]. Thus, osteoblasts and their precursors are always a first starting point for 
different concepts that should improve bone healing [53]. Interestingly, different ions such as $\mathrm{Mg}^{2+}$ ions influence osteoblastic growth, proliferation or differentiation [54,55].

Moreover, influences on bone-resorbing cells and their precursors, i.e., multinucleated osteoclasts and hematopoietic stem cells as well as the different intermediate stages, are of great interest in the field of bone tissue regeneration [56]. This is based on the fact that a molecular cross-talk between osteoblast and osteoclasts has been revealed and additionally, it has been shown that both cell types are organized in so-called bone remodeling units (BRU) or basic multicellular units (BMU) $[57,58]$. On the one hand, osteoblasts play an important role in osteoclastogenesis and bone resorption based on the expression of different molecules such as the receptor activator of NF- $K B$ ligand (RANKL), the macrophage-colony stimulating factor (M-CSF), interleukin (IL)-1 $\beta$, IL-6 and IL-11, amongst others [52,59,60]. Furthermore, osteoblasts also express different inhibiting molecules such as osteoprotegerin (OPG), the granulocyte macrophage-colony-stimulating factor (GM-CSF), IL-3, IL-12 and IL-18, which led to the conclusion that a balanced control of bone remodeling is achieved. On the other hand, different coupling factors are nowadays known that are expressed by osteoclasts such as tartrate-resistant acid phosphatase (TRAP), sphingosine 1-phosphate (S1P), bone morphogenetic protein 6 (BMP-6), hepatocyte growth factor (HGF) and collagen triple helix repeat containing 1 (CTHRC1), amongst others, inducing osteoblastic growth or bone formation [61]. Thus, this cell type constitutes a further approach for enhancement of bone regeneration. In this context, it has already been shown that ions such as $\mathrm{Sr}^{2+}$ ions can influence bone formation via depression of osteoclast-mediated bone resorption (for further details see paragraph 3 ).

Additionally, other cell types such as endothelial cells are involved in the process of bone tissue healing, as sufficient vasculature and the related transport of both nutrients and metabolic end products are basic factors for bone formation [33]. Thus, this cell type and functional blood vessels are also a key factor in the regeneration process. In this context, both the process of bone healing and angiogenesis are directly coupled via different local factors [62]. Primarily, the so-called hypoxia-inducible factor $1-\alpha$ (HIF-1 $\alpha)$ pathway is induced by local hypoxia affected by a bone injury as a key mechanism for coupling bone growth to angiogenesis [63]. The induction of this pathway results in an increased expression of the vascular endothelial growth factor (VEGF), one of the most important and strongest angiogenic cytokines, which is also expressed by osteoblasts and cell types such as macrophages [64]. The expression of VEGF leads to blood vessel ingrowth within the defect area and has a direct influence on osteoblast growth and proliferation as well as matrix deposition [64].

Moreover, the connection between the immune system and bone tissue metabolism and regeneration has been recognized in more detail in recent years. In this context, it has been revealed that a special subtype of the macrophage line within bone tissue, so-called osteomacs, is a further key element for bone formation [65]. Interestingly, these osteal macrophages are also integrated into resting bone tissue and are enriched at sites of bone formation combined with the inflammatory process following bone injury [37]. Following their activation, osteomacs have shown to promote osteoblastogenesis and matrix deposition via the nuclear factor (NF)- $\mathrm{KB}$ signaling pathway, which is important for their pro-osteogenic function [66]. Furthermore, it has been revealed that a direct cell-cell-contact between osteomacs and osteoblasts takes place, ensuring an osteoblastic maintenance and homeostasis via the sequestosome 1/p62-dependent low-level activity of NF- $\mathrm{kB}[65,67]$.

Finally, the reaction of different inflammatory cells to an implanted bone substitute influences the process of bone healing $[68,69]$. Thus, research in the field of biomaterial-induced inflammation has increasingly focused on bone regeneration research. In this context, it has been revealed in the last decades that nearly all bone substitute materials induce an inflammatory cascade, the so-called "foreign body response to biomaterials", after its application [70]. In this cascade, the initial accumulation of proteins, which is highly specific for every biomaterial dependent on its respective physicochemical characteristics, causes the further binding of a first generation of different cells and following inductions of specific signaling pathways [71,72]. This first generation of cells within an implantation bed guide the cellular processes via expression of different molecules or cytokines [73]. Interestingly, it has been 
revealed that in this inflammatory cascade, macrophages and their fused end stages, the so-called multinucleated giant cells (MNGCs), are key cellular components [74,75]. Those cell types have shown to express both pro- and anti-inflammatory molecules such as VEGF that guide the integration behavior and factors such as the implant bed vascularization of bone substitute materials [64,76]. Additionally, other cell types such as granulocytes or thrombocytes have been partially revealed to have an eminent influence on this tissue reaction cascade, which finally leads to different outcomes of the bone regeneration process. Material factors, for example, the chemical composition or physical material properties such as the porosity or the surface structure, as well as the involvement of different ions such as $\mathrm{Cu}^{2+}$ ions, have been shown to influence the inflammatory tissue reaction caused by a bone substitute material $[71,77,78]$.

\section{Metal Ions, Their Physiological Functionalities and Role in Bone Healing}

Metals have been widely accepted as implant materials for a few decades. Even when a solid metal is applied to a physiological environment, it is always in an equilibrium with its ions. These metal ions are responsible for a variety of biochemical functions, which are important for the different steps of bone regeneration, as they influence the equilibrium between osteoblasts, osteoclasts and osteocytes. Thus, metals and their corresponding ions, which have an influence on the process of bone healing, should be mentioned here (Figure 1). We will also outline the impact on different states of tissue formation and the interplay between related metal ions in processes leading to bone regeneration.

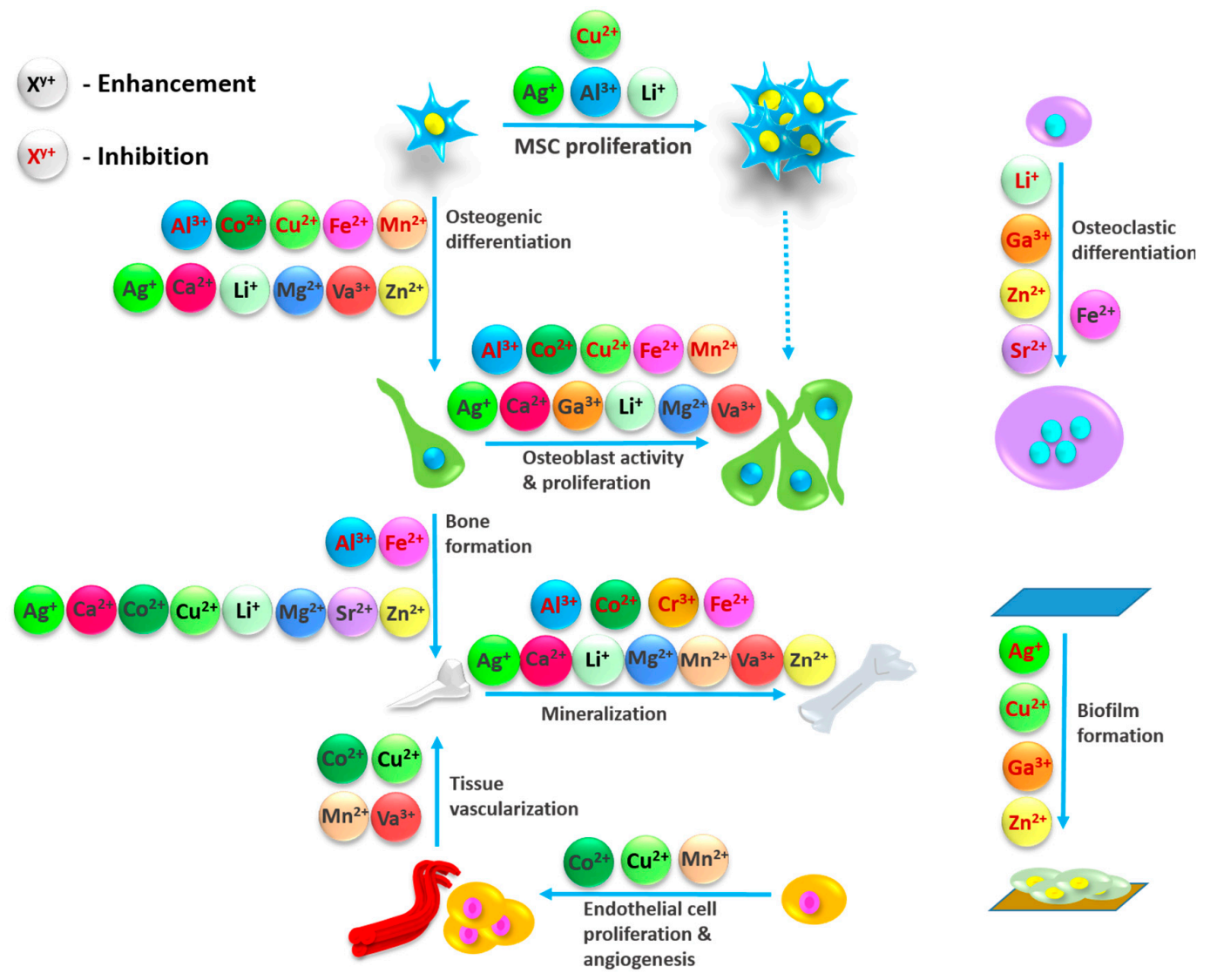

Figure 1. Influence of metal ions on the variety of processes involved in bone regeneration.

\subsection{Aluminum $\left(A l^{3+}\right)$}

Aluminum does not belong to the group of trace elements, is not involved in any physiological functions and is consequently not essential for the human organism [79]. Intake of elevated 
quantities of aluminum is associated with toxic effects leading to serious adverse reactions including anemia, encephalopathy and osteoporosis, as $\mathrm{Al}^{3+}$ ions compete with essential ions like $\mathrm{Fe}^{2+}$ [80-82]. Investigation of the specific reaction of human neural cells to aluminum exposure, for example, showed that concentrations as little as $100 \mathrm{nM}$ of aluminum sulfate significantly elevated atypical, pro-inflammatory and pro-apoptotic gene expression [83].

Reports about the functions of aluminum in bone formation are ambiguous. Positive impacts of aluminum supplementation on osteogenesis in beagles as well as in osteopenic rats was previously demonstrated, initiating a further interest in the investigation of aluminum in tissue engineering $[84,85]$. In contrast to these findings, expression of osteoblast activity markers was substantially lower, while expression of apoptotic markers was increased when treated with aluminum, demonstrating impaired cellular activity and survival, and a clear link between aluminum intoxication and compromised bone formation [86]. Quarles and colleagues put their findings on the positive impact of aluminum on de novo bone formation into context with the contradicting literature and suggested that aside from discrepancies in the applied model/organism, aluminum concentrations and time of exposure, a paradoxical impact of aluminum on mesenchymal progenitors and mature osteoblasts could be the main reason for these dissimilar observations [85]. This hypothesis was further supported by another group, which demonstrated that aluminum ions provoked a chemotrophic stimulus in preosteoblasts while having an inhibitory effect on osteoblasts [87].

Negative impacts of aluminum on osteoblast function, however, are prevalent in the contemporary literature. An in vivo study in rats assessed the effects of aluminum exposure on the uptake of bone mineral elements, trace elements and bone mineral density. The levels of analyzed trace elements were significantly lower with aluminum exposure, and deposition of calcium, phosphorus and magnesium was decreased in comparison to the control population. Bone mineral density in the femur metaphysis of the aluminum-treated group was also significantly lower compared to the control, resulting in pronounced bone loss [88]. Aluminum does not seem to contribute to bone and tissue healing but to have a rather opposing impact on this process so that, aside from favorable mechanical properties, addition of aluminum to implantable medical devices offers no scientifically evident benefits. Furthermore, other bioceramics such as zirconia oxide are progressively emerging as bioinert alternative to aluminum oxide [89].

\subsection{Calcium $\left(\mathrm{Ca}^{2+}\right)$}

Calcium is an important functional component of biodegradable calcium phosphate-based biomaterials designated for bone regeneration in orthopedics, trauma surgery, and in dentistry (for reviews: [90-92]).

Calcium is the most common mineral of the body and is primarily stored in the skeleton [93]. Calcium homeostasis is tightly regulated by the parathyroid hormone (PTH) and calcitonin, which regulate calcium serum levels by stimulating (PTH) or inhibiting (calcitonin) bone resorption mediated by osteoclasts. During bone remodeling, bone resorbing osteoclasts can create local concentrations of extracellular calcium ions up to $40 \mathrm{mM}$ [94]. These microenvironmental increases are known to inhibit resorption activity of osteoclasts and to stimulate proliferation and differentiation of mesenchymal stromal cells [93,95-99] and osteoblasts [100,101].

During the 1980s, extracellular calcium was shown to activate an extracellular G-protein-coupled receptor, termed the calcium sensor receptor (CaSR) [102]. The CaSR is expressed in cells of the hematopoietic lineage, such as in monocytes [103], osteoclasts [104] and in cells of the mesenchymal lineage $[93,99,101,105,106]$. Regarding the high responsiveness of bone cells to extracellular calcium, elevated levels of calcium enhance proliferation chemotaxis and osteogenic differentiation of bone marrow-derived mesenchymal stromal cells in a dose-dependent manner by activating the CaSR [93,99]. Downstream, the intracellular pathway induces phosphorylation of extracellular signal-regulated protein kinases 1 and 2 (ERK 1/2) [99], which are part of the mitogen-activated protein kinase (MAPK) signaling pathway, playing an important role in regulating cell proliferation in various 
mammalian cells [107]. The activation of the CaSR in response to extracellular calcium levels also stimulates phospholipase C (PLC) and induces sustained increase of cytosolic calcium in rat calvarial osteoblasts [106]. The activation of PLC results in generation of inositol 1,4,5-trisphosphate (IP3) and triggers IP3-receptor-mediated calcium release from the endoplasmic reticulum. As a result, store operated calcium entry (SOCE) mediates extracellular calcium entry into the cells for endoplasmic reticulum-calcium store filling [108]. In addition to the effects mediated by the CaSR and the SOCE route, voltage gated calcium channels may also serve as structural units accounting for calcium entry into osteoblasts [106], and osteogenic differentiation of osteoprogenitors [96,109].

Given the superior significance to modulate cellular functions, variations in extracellular calcium in the milimolar range result in proliferation, survival and chemotaxis as well as in differentiation of osteoblasts $[101,106]$ and bone marrow-derived mesenchymal stromal cells (MSCs) [93,96,99]. Optimal conditions to stimulate proliferation of rat calvarial osteoblasts include extracellular calcium concentrations in the range of 3 and $10 \mathrm{mM}$ [101]. Proliferation of bone marrow-derived MSCs harvested from different species (i.e., human, porcine, rat) is effectively supported by concentrations of $4 \mathrm{mM}$ [99], $7.8 \mathrm{mM}$ [96], and $10 \mathrm{mM}$ [93]. Additionally, osteogenic differentiation capacity of human bone-derived MSCs is stimulated in response to extracellular calcium concentrations in the range of 10 and $20 \mathrm{mM}$ [98].

According to the composition of natural bone and the pivotal role of calcium in cellular functions, various calcium phosphate-based materials have been developed for bone replacement therapies [90-92]. Incorporation of the calcium phosphate phases modulates bioactivity of the biomaterials, and as pointed out in previous studies, high bioactivity is equivalent to calcium phosphate binding capacity and causes depletion of calcium in close vicinity to the biomaterial $[97,104,110]$. Calcium phosphate deposition along the surface of bone substitute materials represents an advantageous property to support osseointegration. However, the calcium-deficient microenvironment in close vicinity to the materials remains obscure-especially considering the aforementioned calcium-dependent effects on osteoblasts and progenitor cells. It has been shown that osteoprogenitors-as in the case of bone-derived MSCs-can overcome calcium deficiency when they are cultured in combination with highly bioactive xerogels [97]. The mechanism by which the cells maintain their functional integrity even in response to calcium levels close to zero is still not clear. Given the fact that the materials with high bioactivity are composites, it might be concluded that the beneficial effects on cell survival, proliferation and differentiation are mediated largely by ionic dissolution products such as silica $[97,111]$ or phosphate ions $[112,113]$. According to this, it has been postulated that best results of osteogenic differentiation of osteoblast progenitors along with bone formation may be expected when calcium phosphate-based materials dissociate easily to calcium and phosphate ions [113].

\subsection{Chromium}

The physiological function of chromium in human is currently under debate. Though some cellular functions of chromium have been reported, in 2014, the European food safety authority officially removed it from their list of essential micronutrients $[114,115]$. The impact of chromium exposition on osteoblasts was investigated in several studies, whereby only toxic effects, causing reduced DNA, RNA and protein synthesis, were reported [116,117]. Furthermore, chromium suppressed collagenase activity in osteoblasts, which reduced collagen formation and deposition and also negatively affected new bone formation [117].

In the field of reconstructive medicine, cobalt-chromium $(\mathrm{CoCr})$ is one of the main alloys used for total hip arthroplasty. However, the $\mathrm{Co}^{2+}$ ion released from $\mathrm{CoCr}$ surfaces has been reported to severely impact mesenchymal stem cells by altering osteogenic gene expression, affecting osteogenic lineage differentiation and compromising the mineralization process [118]. The impairment of bone formation by chromium and cobalt was further analyzed by the effect of these ions on the expression of various TGF- $\beta$ isoforms and mineralization in MG-63 and Saos-2 osteosarcoma cells, as well as in primary 
human osteoblasts. While $\mathrm{Co}^{2+}$ decreased the expression of different TGF- $\beta$ isoforms in all investigated cell types, $\mathrm{Cr}^{3+}$ had no impact. $\mathrm{Cr}^{3+}$, on the other hand, strongly inhibited the mineralization process of these cells in vitro, whereas $\mathrm{Co}^{2+}$, within the range of the tested concentrations, showed no inhibitory effects on mineralization [119].

\subsection{Cobalt $\left(\mathrm{Co}^{2+}\right)$}

As cobalt is a compound of cobalamin, it is an essential trace element, which stimulates the production of red blood cells and promotes angiogenesis by activating hypoxia-inducible transcription factors (HIF) [120-122]. Previous studies have demonstrated a rather unfavorable effect of $\mathrm{Co}^{2+}$ ions released from $\mathrm{CoCr}$ surfaces, affecting osteogenic lineage differentiation of hMSCs, TGF- $\beta$ isoform expression in osteoblasts and the mineralization process. Conversely, recent data indicate that the impaired mineralization reported by Schröck and colleagues was caused by $\mathrm{Cr}^{3+}$ ion release, rather than by $\mathrm{Co}^{2+}$ ions $[118,119]$.

The angiogenic capacities of cobalt ions sparked the idea of incorporating this metal into different materials used for bone healing in order to stimulate vascularization of implanted grafting materials and thereby enhance the remodeling processes and supporting overall regeneration. The impact of $\mathrm{Co}^{2+}$ ions incorporated into calcium phosphate (CaP) coatings for poly-lactic acid (PLA) particles on new blood vessel formation was studied in an intramuscular implantation model in goats. The inflammatory reaction, following a 12-week implantation course, demonstrated no pathologic differences between PLA particles coated with solely CaPs or those coated with $\mathrm{Co}^{2+}$ containing CaPs. Formation of blood vessels was significantly increased when $\mathrm{Co}^{2+}$ containing CaP-coated PLA particles was implanted, and vessel size was notably increased, suggesting a positive impact of $\mathrm{Co}^{2+}$ on vascularization in vivo [123].

The impact of $\mathrm{Co}^{2+}$ containing CaPs on osteoporotic alveolar bone regeneration was further investigated in rats. Biocompatibility assessment of the material was approved for epithelial Caco-2 and osteoblastic MC3T3-E1 cells, whereby no toxic effects were observed in Caco-2 cells; however, a considerable decrease in cell viability and impairment of cytoskeletal organization was observed in the MC3T3-E1 cells. Despite the negative impact of $\mathrm{Co}^{2+}$ ions on osteogenic cells, hydroxyapatite (HAp) nanoparticles doped with $\mathrm{Co}^{2+}$ demonstrated dose-dependent acceleration of osteogenesis, osteoporotic bone regeneration and graft material substitution in comparison to HA-nanoparticles without $\mathrm{Co}^{2+}$. The authors listed several hypotheses for their observations, including increased transport of $\mathrm{Ca}^{2+}$ ions into the extracellular fluids facilitated by the moderate toxicity of $\mathrm{Co}^{2+}$ ions as well as increased cytokine production and release, which could potentially boost aminopeptidase activity together with migration and proliferation of endothelial cells [124].

The combination of $\mathrm{Co}^{2+} \mathrm{HAp}$ nanoparticles with blood or plasma rich in growth factors (PRGF) was shown to induce the generation of large quantities of osteoblasts, increase mineralization and accelerate bone regeneration [124]. Taking into consideration that recent studies demonstrated impaired growth factor expression and osteogenic lineage determination in hMSCs exposed to $\mathrm{Co}^{2+}$, these observations seem reasonable, as blood and PRGF may compensate for this lower expression, thus enabling proper osteogenic lineage differentiation [119]. Furthermore, the study indicates that bone minerals containing scaffolds, as presented in this study, are suitable for cobalt incorporation, as cobalt does not impair but rather seems to support the mineralization process [119,124].

Similar findings were reported by another group, who developed a hydrogel with incorporated $\mathrm{Co}^{2+}$ ions. Hydrogels solely doped with $\mathrm{Co}^{2+}$ did not increase the amount of regenerated bone volume, bone surface and bone surface density in a rat model in vivo, whereas the addition of BMP2 to the hydrogel did. The observed gain was even more pronounced with the simultaneous loading of $\mathrm{Co}^{2+}$ and BMP2 onto the hydrogel, which again favors the hypothesis of a synergistic effect of $\mathrm{Co}^{2+}$ in conjunction with growth factors in graft vascularization and bone regeneration [125]. Increased collagen deposition, new bone formation and bone hardness were also reported for cobalt-containing bioglasses compared to bioglasses without cobalt in critical size defects in a rabbit's femur in vivo [126]. 
Additionally, the authors showed that the inclusion of both strontium and cobalt into the bioactive glasses even further ameliorated the bone regeneration process.

\subsection{Copper}

While $\mathrm{Cu}^{2+}$ is in the most stable oxidation state in aqueous solution, it can also be present as $\mathrm{Cu}^{+}$in the human body exhibiting diverse properties and functions [127]. Together with iron and zinc, copper is one of the most important metals for humans and is especially needed to generate $\mathrm{Cu}$-proteins that have enzymatic functions. Cu-proteins have three main functions in living organisms, such as participation in electron-transfer reactions, transport of oxygen and transport or storage of the metal itself.

Therefore, copper is involved in multiple physiological functions, including the regulation of bone metabolism and turnover. $\mathrm{Cu}$ imbalances also affect the nervous system and can lead to vascular abnormalities in the human body. The impact of copper deficiency on skeletal growth and development was previously assessed in several studies $[128,129]$. Copper became a material of interest in the field of bone regeneration due to its antibacterial properties and its ability to stimulate collagen fiber deposition and angiogenesis, which represents the first step towards the formation of vital and vascularized tissue [130-132]. The effect of copper-doped silicate bioceramics on vascularization was subjected to several studies. Kong and colleagues [133] recently reported a positive impact on the expression of angiogenic growth factors in human umbilical vein endothelial cells (HUVECs) and human dermal fibroblasts (HDFs) in response to $\mathrm{Cu}^{2+}$ released from copper silicate bioceramics. Thus, the release of $\mathrm{Cu}^{2+}$ ions from porous matrices like bioactive glass should facilitate the ingrowth of bone into the scaffold matrix [134].

Current data support enhanced osteogenic differentiation of mesenchymal stem cells mediated by copper supplementation. Early studies on the effect of copper on MSCs derived from postmenopausal women demonstrated reduced proliferation, a 2-fold enhancement of differentiation into osteoblasts and increased calcium deposition, while alkaline phosphatase activity was considerably diminished in these cells and shifted to an earlier timepoint [135]. Similar findings on the suppression of alkaline phosphatase activity mediated by copper exposition were observed in rat MSCs by Li and colleagues, who reported a clear reduction in osteogenic differentiation of rat MSCs concomitant with the reduction of several osteogenic genes, alkaline phosphatase activity and bone nodule formation. In addition, cytoskeletal abnormalities during osteogenesis were found in these cells. The process of ectopic bone formation in a rat model was also significantly impaired by the presence of copper and while vascularization in the regenerated soft tissue was promoted, collagen formation was strongly inhibited [136].

These findings are supported by a study conducted with pre-osteoblastic MC3T3-E1 cells cultured on copper containing bioglasses. While no effects on proliferation and alkaline phosphatase activity of these cells were noted with scaffolds doped with $0.4 \mathrm{wt} . \%$ to $0.8 \mathrm{wt} . \% \mathrm{CuO}, 2.0 \mathrm{wt} . \%$ showed a significant reduction effect on both. In an in vivo approach, rat calvarial defects showed that a higher concentration of $\mathrm{Cu}^{2+}$ ions also substantially reduced new bone formation from $46 \pm 8 \%$ to $0.8 \pm 0.7 \%$, while lower concentrations showed no such impairment. On the other hand, the authors found a stimulatory effect on blood vessel formation dependent of the copper content of the scaffolds, with the greatest impact seen for the highest concentration of $2.0 \% \mathrm{CuO}$ [137]. Benefits of copper supplementation in the regeneration of critical-sized calvarial defects in rats were further reported by the comparison of chitosan scaffolds and chitosan scaffolds doped with copper. Analysis of micro-CT scans after 4 weeks of healing indicated twice the amount of bone volume in the defects treated with copper containing chitosan scaffolds as compared to scaffolds without copper [138].

\subsection{Gallium $\left(G a^{3+}\right)$}

Gallium is a metal that serves no known essential functions in human. While currently being investigated in cancer treatment because of its anti-proliferative properties resulting from the 
interference with iron-dependent cellular functions, studies also demonstrated that short-term gallium treatment reduces bone turnover in vivo and increases the calcium content of bone in patients suffering from cancer-related hypercalcemia [139]. Furthermore, gallium has the potential to disrupt microbial iron utilization by interacting with iron-binding bacterial molecules called siderophores. In this manner, gallium downregulates bacterial iron uptake and impairs bacterial growth [140]. Gallium-EDTA-coated titanium chips exhibited significant antimicrobial activity against Escherichia coli for more than 28 days after coating, underscoring a promising application of gallium-based coatings for effective prevention of biofilm formation, and these chips could be used in dental and orthopedic reconstructive surgery [141]. Additionally, gallium-coated titanium implants showed superior antibacterial properties in vivo and consequently, more effective prevention of biofilm formation than silver coatings [142].

Several studies analyzed the effect of gallium administration on osteoclasts and osteoblasts. While osteoclastic lineage differentiation and resorption activity were lowered by gallium, no impact on viability and proliferation of osteoblasts was noted [143]. In an in vivo approach using a rabbit femoral defect model, gallium-loaded calcium phosphate cements showed no superiority over calcium phosphate cements without gallium in terms of bone healing, whereby the authors implied that no effect was observed due to the low resorption of the material and consequently, low release of $\mathrm{Ga}^{3+}$-ions [144]. In a subsequently conducted study, the gallium release from Ga-CaP was optimized and re-evaluated for its beneficial properties in bone healing. Upregulation of osteoblastic marker expression was observed in primary human osteoblasts cultured on the Ga-CaP, whereby late osteoclastic markers were downregulated in primary human monocytes that were previously induced towards the osteoclast lineage.

The in vivo properties of Ga-loaded CaPs in new bone formation were assessed in a murine bone defect healing model; aside from an enhanced total defect-fill, Ga-CaPs also promoted the synthesis of mature organized collagen [145]. With respect to the current literature, gallium holds a set of promising qualities for future applications in tissue engineering.

\section{7. $\operatorname{Iron}\left(F e^{2+}\right)$}

Iron is one of the most important ions in the human organism as it is essential for a variety of cellular processes [146-148]. Different cellular effects such as the synthesis of deoxyribonucleic acid (DNA) and ribonucleic acid (RNS), proteins, electron transport processes, cellular proliferation and differentiation are related to iron ions $[149,150]$. These effects are based on the involvement of iron ions mainly as components of enzyme molecules, such as oxidases, catalases, peroxidases, aconitases, ribonuleotide reductases and nitric oxide synthases, amongst others [150-152]. As a coordinating ion in the center of hemoglobin and myoglobin, iron is an essential trace element, required for oxygen transport and regulation of several metabolic enzymes $[153,154]$. Iron is the loosely bound ion component of the procollagen proline hydroxylase and the procollagen lysine hydroxylase [155]. Both enzymes effect the hydroxylation of proline and lysine residues in the precursors of collagen. Large amounts of iron released from iron-containing implants, however, may cause excessive iron levels in the blood. Here, the free iron can react with peroxides and trigger the formation of free radicals, which are highly reactive and damage lipids, proteins, DNA as well as cellular structures [156,157]. Additionally, hemochromatosis has been demonstrated to result in osteoporosis mediated by increased ferroxidase activity of ferritin. In vitro experiments demonstrated inhibition of osteogenic lineage differentiation in human osteoblasts concomitant with decreased calcification caused by iron overload [158-160]. In vivo experiments in zebrafish larvae demonstrated that the mechanism by which iron-overload causes impaired osteoblast function and mineralization is based on the increased generation of reactive oxygen species. Application of deferoxamine, an iron chelator capable of removing whole-body iron, ameliorated the iron-induced negative effects on osteoblastic marker expression and mineralization [161]. Similarly, this was also observed for hepcidin, a regulator of iron-uptake, which is also capable of removing whole body iron. Likewise, hepcidin downregulation elevates the iron level and causes iron-overload mediated interference with osteogenesis [162]. 
Iron exposure to human bone marrow mesenchymal stem cells (BMSCs) decreased their differentiation towards the osteogenic lineage as well as extracellular matrix mineralization with a total block of lineage commitment at a concentration of $50 \mu \mathrm{M}$. In vivo experiments in mice were able to reproduce these findings. The inhibitory effect of iron, however, was specific for osteogenic lineage differentiation, whereas no impact on chondrogenesis and adipogenesis was noted [163]. Furthermore, the promotion of osteoclast formation mediated by iron was previously reported, which additionally underscores the unfavorable features of iron for the purpose of biomedical tissue engineering [164]. In contrast to these previous results, Wang and colleagues reported a positive impact of iron oxide nanoparticles (IONPs) on the osteogenic differentiation of human BMSCs in vitro mediated by MAPK signaling. The authors speculated that the negative impact of iron on osteogenesis observed in previous studies resulted from increased reactive oxygen species (ROS) formation and ferritin activity, whereby this process is proposed to be prevented by nanoparticle formulations [165]. Moreover, Zhao and colleagues analyzed both effects of excessive and low body iron conditions on osteoblast activity [166]. The results showed that an increased iron concentration inhibited osteoblastic activity in a concentration-dependent manner, while a mild iron deficiency led to an increase in cellular activity. In contrast, a severely low iron level completely inhibited osteoblastic differentiation. An enhanced osteoclast formation is one result of an increased iron concentration while osteogenic stimuli are blocked under the same conditions [167]. Thus, further studies will have to clearly determine the potential benefits of iron in tissue engineering.

\subsection{Lithium $\left(\mathrm{Li}^{+}\right)$}

Lithium is a non-essential trace element and consequently fulfills no known functions in the human organism. However, due to its beneficial impact in the treatment of psychological disorders, lithium has been widely introduced into medical applications [168]. Among the various mechanisms of action that have been proposed for lithium, the stimulation of neural progenitor cell proliferation by the Wnt/ $\beta$-catenin pathway, which leads to an increase of the brains grey matter, is widely accepted $[169,170]$. Interestingly, the proliferation of other cell types such as MSCs is also regulated by the Wnt/ $\beta$-catenin pathway, suggesting that lithium might also modulate the proliferation of these cells [171]. In fact, a recent study reported increased proliferation of hMSCs stimulated by lithium-mediated Wnt/ $\beta$-catenin signaling in vitro [172]. Additionally, previous studies reported this pathway to be a main regulator of osteoblastogenesis, which made lithium application in the field of tissue engineering even more appealing [173]. Though few studies reported a beneficial impact of lithium supplementation on bone mineral density and a reduction of the risk of fracturing, the molecular mechanisms by which lithium facilitates these effects are not yet completely understood [174,175]. In a transcriptome-based approach used to identify the impact of lithium on osteoblastogenesis, Satija and colleagues reported diminishing proliferation of hMSCs treated with lithium and decreased expression of adipogenic and osteoclastogenic factors accompanied by the induction of osteoblastogenic markers associated with collagen-1 deposition and mineralization; similar results were also reported by other groups [176-178]. Systemic lithium application exhibited beneficial effects on bone healing following distraction osteotomy in the tibia of rats. Bone mineral density, the quantity of newly formed mature bone tissue and bone mass regeneration were increased in rats who received a lithium solution through gastric gavage in comparison to those receiving a saline solution, pointing to accelerated callus ossification and bone healing mediated by lithium [179].

To further utilize the beneficial effects of lithium on bone regeneration, various biodegradable lithium-containing scaffolds have been developed and tested for their potential in bone regeneration; preliminary experiments on lithium release, toxicity and osteoblastic cell activity on such scaffolds were promising $[180,181]$. In vitro experiments comparing pure HAp with lithium-doped HAp scaffolds demonstrated increased osteoblast activity, resulting in accelerated material degradation, and the degradation products exhibited no toxic impacts on osteoblasts and enhanced osteoblast proliferation. Additionally, compressive strength testing revealed favorable mechanical properties 
of lithium-doped HAp scaffolds [182]. Further evidence on the beneficial impact of lithium incorporation into calcium phosphate cement scaffolds on bone healing was recently demonstrated. Lithium release from this material stimulated the proliferation and differentiation of osteoblasts in vitro by Wnt/ $\beta$-catenin activation. Application of lithium-doped calcium phosphate cements significantly increased osteogenesis and defect repair in vivo and showed superior osteoconduction and osteointegration compared to pure calcium phosphate cements [183]. Overall, the literature emphasizes that lithium regulates growth and development of osteogenic progenies while suppressing osteoclast development; identification of the exact mechanisms of lithium orchestrating either differentiation or proliferation of osteoblasts represents a pivotal goal for future clinical applications. Nonetheless, lithium seems to directly regulate and benefit osteogenic lineage cells, whereas other metallic ions, such as copper and cobalt, seem to impact bone regeneration by their impact on endothelial cells and accelerated vascularization.

\subsection{Magnesium $\left(\mathrm{Mg}^{2+}\right)$}

Magnesium is an alkaline earth metal that belongs to group 2 metals of the periodic table. The mammalian body consists of approximately $0.4 \mathrm{~g}$ magnesium $/ \mathrm{kg}$ body weight [184]. More than $90 \%$ is bound and stored in bone, muscle and non-muscular soft tissue [184,185], while only a small amount (1-5\%) [185] resides in extracellular fluids [186] in the form of ionized/free magnesium $(55-70 \%)$ or is bound to proteins and anions [184].

Magnesium is an important intracellular cation [185-187] as it is cofactor for more than 300 enzymatic reactions, essential for the synthesis of proteins and nucleic acids $[185,188]$ and for the transport of both, potassium and calcium ions [185]. Magnesium is also crucial for transphosphorylation of ATP, and changes of intracellular magnesium levels might influence several pathways [189].

As magnesium maintains bone strength [185] and bone formation capacity, [184] adequate dietary magnesium plays a major role in musculoskeletal health and is relevant to prevent osteoporosis [190]. A magnesium deficiency exerts negative effects on rat bone metabolism, systemic bone mass [191], and contributes to osteoporosis in humans [189]. It has been proposed that the effects of magnesium deficiency might be the result of increased levels of TNF $\alpha$, IL-1 [192], and NF-KB ligand (RANKL), along with decreased serum levels of osteoprotegerin (OPG) [193].

According to the superior role of magnesium in cellular functions, magnesium-based materials are regarded as promising candidates for bone replacement therapies due to the stimulation capacity of bone cell differentiation in vitro [194-197] and bone formation in vivo [198-201]. Currently available materials include different magnesium-containing compounds such as oxides, phosphates and silicates that are used as bone cements, bone scaffolds or implant coatings. Overviews of the different magnesium-based materials-such as bioceramics, e.g., magnesium phosphates $\left(\mathrm{MgO}-\mathrm{P}_{2} \mathrm{O}_{5}\right)$, calcium magnesium phosphates $\left(\mathrm{CaO}-\mathrm{MgO}-\mathrm{P}_{2} \mathrm{O}_{5}\right)$, and magnesium glasses $\left(\mathrm{SiO}_{2}-\mathrm{MgO}\right)$ [202] are given in recent systematic reviews [203-215].

Numerous in vitro studies focus on the effects of magnesium ions on bone cells, in terms of enhancing proliferation and migration as well as alkaline phosphatase (ALP) activity of human osteosarcoma MG-63 cells [216], increasing viability and differentiation capacity of a human osteoblast cell line (hFOB1.19, ATCC) [217], cell proliferation of bone marrow derived stromal cells (BMSC), and expression of $\alpha 2$ und $\alpha 3$ integrins [218]. However, additional data provide evidence that the effects of magnesium ions develop dose-dependently [217]. Concentrations of about $1-3 \mathrm{mM} \mathrm{Mg}^{2+}$ stimulate gap junctional intercellular communication (GJIC) of osteoblasts [217], while viability, proliferation and differentiation of human BMSCs are ensured by concentrations in the range of 2.5-10 mM [216,218-220].

In contrast, decreased mineralization capacity and matrix deposition of BMSCs have been observed in response to magnesium concentrations higher than $1.3 \mathrm{mM} \mathrm{Mg}^{2+}$ [221-223]. According to the role of magnesium as a physiological calcium antagonist [222], it has been suggested that magnesium substitution for calcium in hydroxyapatite structure [224] and/or modulations of 
intracellular calcium oscillations with consecutive suppression of spontaneous ATP release and inactivation purinergic receptors are responsible for the decreased mineralization capacity of the cells [221]. Additionally, magnesium has a competitive role against Matrix gla protein (MGP), suggested as a potent inhibitor of HAp crystal growth during mineralization [225]. These results are consistent with emerging studies demonstrating significant suppression of mitochondrial accumulation of calcium ions in MSCs [222] and inhibition of excess calcium-induced mineralization in response to high extracellular magnesium [226]. Similarly, decreased intracellular calcium concentration and decreased calcium influx have been observed when MSCs have been cultured in the presence of a high magnesium concentration [223]. Competition between calcium and magnesium ions for the same ion transporters, such as transient receptor potential cation channel, subfamily $\mathrm{M}$, member 7 (TRPM7) [223] and/or inhibition of expression of calcium-sensing receptor (CaSR) [226], might be responsible for the decreased mineralization capacity. In terms of how high concentrations of $\mathrm{Mg}^{2+}$ ions modulate bone cell metabolism and bone cell function, the Wnt/ $\beta$-catenin anti-calcifying pathway and the magnesium transporter SLC41A1 have been shown to be involved in magnesium-mediated signaling of BMSCs [223].

The benefit of biodegradability is that it avoids a second surgery for implant removal and prevents formation of foreign body giant cells in close vicinity of permanent implants, and this has been designated as a major advantage of the magnesium-based materials [227]. The architecture and pore structural conditions of magnesium-enriched scaffolds greatly influence bone formation and remodeling activities [228]. Hydrogen gas released during degradation of magnesium-enriched scaffolds enlarges pre-existing pores, and expands the space for invading cells and blood vessels [201]. Given these beneficial effects, magnesium-based materials have emerged as a new class of biodegradable biomaterials for bone tissue engineering-referred to as next-generation biomaterials [227].

However, considering the rapid degradation rates, magnesium-based implants are still not commonly used in clinical practice $[212,227,229]$. The "high magnesium microenvironment" created by rapid corrosion of magnesium alloys might disturb calcium-dependent processes and physiology of the cells localized in close vicinity to the implants [222]. Therefore, the balance between calcium and magnesium ions is not only crucial for bone physiology [222] but also for successful osseointegration of magnesium-based materials.

Additionally, due to rapid corrosion rates, magnesium-based implants have the risks of structural failure and toxic responses immediately after implantation [227]. In the course of degradation, magnesium hydroxide and hydrogen gas are produced, both of which cause detrimental effects on cells and tissue localized close to the implant $[188,230]$. Controllable in vivo corrosion rates, in terms of establishing sufficient corrosion protection methods at different levels might represent promising tools to overcome these disadvantages $[188,212,227,229,230]$.

\subsection{Manganese $\left(\mathrm{Mn}^{2+}\right)$}

Manganese is an essential element and is crucial for the proper function of a multitude of enzymes in living organisms [231]. Divalent cations such as $\mathrm{Mn}^{2+}$ are also known to influence cell migration by modulating focal adhesion organization via integrins and actin stress fiber formation [232,233]. These properties make manganese an interesting candidate for improving ingrowth and integration of bone grafts and other implantable materials alike. The impact of manganese on MG-63 osteoblastic cells was evaluated in order to confirm this theoretical benefit of manganese supplementation in the process of new bone formation. Manganese supplementation reduced cell proliferation, migration, ERK/MAPK-signaling and collagen I as well as alkaline phosphatase expression in a dose-dependent manner. Interestingly, the mRNA level of bone sialo protein (BSP) was increased by manganese exposure, whereas the BSP protein level was not elevated [234].

Interestingly, doping alumina tubes with manganese significantly enhanced tissue maturation and osteogenesis in vivo in rats; the authors noted that the surface structure of the alumina tubes 
was altered by manganese incorporation which made it impossible to distinguish whether the observations resulted from the phase composition or the surface topography modification [235]. However, manganese is also reported to have insulin-mimetic properties and other properties within this class, such as VAC-increased fracture site vascularization by local application, which led to the hypothesis that manganese might also accelerate fracture healing [236,237]. In fact, a group reported a significant increase in the mechanical properties of bone, mineralized tissue formation and VEGF-expression in a rat femoral fracture model when manganese chloride $\left(\mathrm{MnCl}_{2}\right)$ was supplemented. Additionally, blood vessel density was dramatically increased by $\mathrm{MnCl}_{2}$ treatment, suggesting increased vascularization, fracture healing and osteogenesis, implicating a potential function for manganese in tissue engineering [238].

\subsection{Silver $\left(\mathrm{Ag}^{+}\right)$}

Due to its antimicrobial properties, silver has a long history of application for medical purposes, whereas the investigation of potential functions of silver in bone regeneration is a quite recent occurrence [239]. Analysis of the tissue response to silver acetate-coated Dacron vascular grafts implanted into the dorsal skinfold chamber in mice revealed higher functional capillary density without affecting inflammatory host tissue response, collagen formation, apoptosis and cell proliferation as compared to uncoated grafts [240]. Furthermore, functionalization of silver nanoparticles in tissue regeneration has already been introduced into commercially available wound dressings, as they exhibit outstanding anti-microbial and anti-inflammatory properties [241-243]. Additional arguments for the utilization of silver nanoparticles instead of other silver formulations like silver nitrate in tissue engineering were recently reported by Quin and colleagues [244]. They showed that the lowest toxic concentration of silver nanoparticles in urine-derived stem cells was substantially higher than that assessed for silver nitrate. More interestingly, however, was the reported promotion of osteogenic lineage induction and actin polymerization of these cells, which was only observed for AgNPs, and not for $\mathrm{AgNO}_{3}$ [244]. In fact, the stimulatory impact of AgNPs on the mineralization of MC3T3-E1 osteoblastic cells maintained by miRNA-mediated increased expression of genes associated with bone formation was previously reported [245].

In order to identify putative impacts of AgNPs in the process of osteogenic lineage induction, the entire transcriptome of MC3T3-E1 cells in response to AgNP exposure was analyzed. The authors found that, aside from the upregulation of different bone morphogenic proteins important for osteogenesis, the enhancement of osteoclastic marker expression was the most pronounced transcription-based alteration [246]. Based on the stimulatory properties of AgNPs on keratinocyte proliferation and migration and fibroblast differentiation, which contributes to the promotion of wound contraction, the impact of AgNPs on proliferation and differentiation of MSCs was analyzed [247,248]. AgNPs successfully promoted MSC proliferation and osteogenic differentiation in vitro. In vivo experiments using a femoral fracture model in mice support the preliminary observations, as AgNPs encapsulated in collagen were able to accelerate callus formation and fracture gap closure. Though the exact impact of AgNPs in this process remains elusive, the authors suggested that the possible chemotactic impact of AgNPs on MSCs and fibroblasts, as well as induction of MSC proliferation and osteogenic differentiation, was responsible for the observed effects [249]. Despite the here reported beneficial impacts of AgNPs on hard-and soft-tissue related cells, further studies will have to elucidate the clinical practicability relevance of AgNPs application in the promotion of osteogenesis.

\subsection{Strontium $\left(\mathrm{Sr}^{2+}\right)$}

Strontium (Sr) is an alkaline earth metal and belongs to the group 2 elements of the periodic table. Although it is considered as a non-essential element, there is growing interest concerning the effects of Sr on cells of the bone. This interest is based upon the fact that strontium ranelate has been used in Europe as a therapeutic drug for the treatment of osteoporosis since 2004. Osteoporosis is a serious systemic skeletal disorder and is becoming a major health problem due to rapid population aging. 
As osteoporosis leads to dramatic changes of the skeleton in terms of markedly decreased bone mass and reduced bone quality, as well as altered architecture at the macroscopic and microscopic levels, the disease is associated with a high incidence of osteoporotic fractures.

The use of Sr for the treatment of osteoporosis is based upon its dual mode of action: Sr influences both osteoblasts and osteoclasts and gives rise to increased bone formation capacity of osteoblasts and decreased bone resorption activity of osteoclasts [250-254]. Due to its similarity to calcium, the effects of $\mathrm{Sr}$ are largely mediated by the calcium sensing receptor (CaSR), which is a membrane-bound receptor expressed in osteoblasts and osteoclasts [255-258]. In response to Sr, intracellular signaling pathways are activated, resulting in enhanced proliferation and differentiation of mesenchymal stem cells and osteoblasts along with increased mineralization and deposition of extracellular matrix $[250,255,259]$ by activating the Wnt/Catenin signal pathway [250,260]. Additionally, in response to the activation of this pathway, OPG (osteoprotegerin) levels of osteoblasts and their precursors increase, whereas RANKL (receptor activator of nuclear factor $\mathrm{kB}$ ligand) expression of the cells decreases [261]. The expression patterns in favor of OPG suppress differentiation of osteoclasts and limit the extent of bone resorption. Similar effects are observable in the course of direct interaction of Sr with the extracellular domain of the CaSR: downstream cascades stimulate diacylglycerol (DAG9-protein kinase C (PKC) ßII which in turn induces osteoclast apoptosis [257]. In a recent in vitro study, Sr could be detected by means of mass spectrometry within the cytoplasm of osteoclasts which were cultivated in combination with a Sr-enriched calcium phosphate cement. Cell differentiation of the osteoclasts was therefore delayed [262]. However, the mechanism by which the ions enter the cells, and to what extent intracellular Sr deposition influences cell signaling, must still be clarified.

Besides the beneficial effects on bone metabolism, systemic administration of strontium ranelate increases the risk of cardiovascular diseases [263]. Therefore, its use is restricted to patients who show no signs of heart and circulatory diseases.

For the benefit of osteoporotic patients and in light of the effects of $\mathrm{Sr}$ on bone remodeling, combinations of Sr with bone substitutes might represent a successful approach to overcome the adverse effects of systemic administration of strontium ranelate. Accordingly, $\mathrm{Sr}$ is used for apatite coatings of orthopedic and dental implants [264-266], and is incorporated into different bone cements [262,267-273]. Because of their subsequent substitution by natural bone in the course of physiological remodeling, it has been proposed that calcium phosphate-based cements ensure the local release of Sr [274], and therefore might represent ideal bone substitutes for the osteoporotic bone. According to this suggestion, stable incorporation of Sr into the crystal lattice of the bone mineral is based upon remodeling activities of osteoblasts and osteoclasts (for a review see [275]), and Sr uptake is especially high in newly formed bone tissue [276]. So placed at the disposal of the bone cells, Sr might locally regulate their activities as well as the bone healing process in the course of further remodeling.

\subsection{3. $\operatorname{Vanadium}\left(V^{+}\right)$}

Vanadium is a trace element present in basically all living organisms and is predominantly stored within the bone tissue [277]. Because of its growth factor mimicking properties, it was previously suggested that vanadium might positively influence osteogenesis $[278,279]$. An early study analyzing the impact of vanadium derivatives on osteoblast-like UMR106 cells reported enhanced proliferation, alkaline phosphatase activity and even differentiation [280]. As insulin supplementation ameliorates negative effects of diabetes on bone regeneration and local insulin treatment enhances fracture healing in healthy rats, the insulin-mimetic properties of vanadium are currently being investigated as a safe and cost-efficient alternative to insulin supplementation [281,282].

Intramedullary delivery of an organic vanadium salt (vanadyl acetylacetonate) in a rat femoral fracture model significantly promoted cell proliferation, vascular endothelial growth, callus cartilage formation and mineralization and considerably increased torque to failure compared to treatment with saline control solutions [236]. A vanadium-loaded collagen scaffold was recently described by Cortizo and colleagues; although vanadium loading increased membrane permeability, no changes 
in the collagen structure were observed. Furthermore, attachment, growth and osteoblastic as well as chondrocytic differentiation of rBMPCs was improved by loading vanadyl acetylacetonate onto collagen membranes [283]. Vanadium coating of titanium implants was also shown to enhance fibroblast attachment and proliferation, which suggests potential benefits in soft tissue healing by vanadium treatment [284]. Taken together, published data demonstrate vanadium to be an interesting metal with great potential in regulating both angiogenesis and osteogenesis; however, further studies are required to support these preliminary findings.

\subsection{4. $\operatorname{Zinc}\left(\mathrm{Zn}^{2+}\right)$}

Zinc is an essential trace element that is pivotal for proper immune system functioning, cell division and for skeletal development and therefore has been implemented into biomaterials for orthopedic and dental applications [285-287]. Furthermore, zinc and zinc alloys are promising biomaterials as load-bearing scaffolds as they have similar mechanical properties to mammalian bone, especially $\mathrm{Zn}^{2+}$ ions, which have a multitude of physiological functions. Zinc led to increased ECM mineralization in hMSC culture by promoting the expression of ALP and osteopontin [288]. Also, with respect to SMCs, a concentration-dependent behavior was found in the presence of $\mathrm{Zn}^{2+}$ in vitro. In the range $80-120 \mu \mathrm{M}$, a change in biological response was observed by inhibition of viability and proliferation [289]. When $\mathrm{Zn}$ was used in different titan coatings, the measured expression of Zn-transporters (ZnT1 and ZIP1) suggested that cells prefer $\mathrm{Zn}^{2+}$ present at the biomaterial interface rather than plain diffusion of $\mathrm{Zn}^{2+}$ ions in the surrounding medium [290]. Additional studies on the actions of zinc supplementation in osteogenesis reported enhanced collagen deposition and mineralization of osteoblast like MC3T3-E1 cells, antagonizing effects on osteoclastogenesis with simultaneous promotion of osteoblastogenic differentiation and increased osteoblast activity mediated by zinc supplementation in a concentration-dependent manner [291-293]. Zinc phosphate-loaded barrier membranes showed excellent anti-microbial properties, capable of inhibiting bacterial colonization upon membrane exposure and avoiding potential infections [294]. To further analyze beneficial properties of zinc in GBR procedures, cross-linked gelatin membranes loaded with zinc hydroxyapatite powder were compared to cross-linked collagen membranes in a rat calvarial defect model. After a period of 6 weeks, bone defect fill was $80 \pm 2 \%, 60 \pm 5 \%$ and $40 \pm 2 \%$ for the zinc-loaded gelatin membrane, the collagen membrane and the unfilled control group, respectively, demonstrating the tremendous potential for the application of zinc in bone regeneration approaches [295]. Antibacterial effects, excellent biocompatibility and stimulatory impact on the activity of osteoblast-like MG63 cells were also recently reported for nanocomposites of carboxylated graphene oxide sheets decorated with zinc oxide nanoparticles, emphasizing the potential application of zinc in nanoparticle formulations for tissue engineering [296].

Zinc ions released from zinc-doped tricalcium phosphates were able to enhance TRAP and ALP activity of hBMSCs and to regulate multinuclear giant cell formation and activity of RAW264.7 macrophages [297]. De novo bone formation in a canine ectopic implantation model was only induced by the addition of zinc to TCPs, however, not by TCPs alone, whereby the rate of new bone formation was coherent with zinc concentration [297]. Zinc is also an attractive candidate for the development of coatings in order to promote the integration of implants. Regarding this matter, a study analyzed rBMSC activity in response to zinc-loaded titanium oxide coatings and the impact of zinc-supplementation on osseointegration in a rat implantation model. In comparison to $\mathrm{TiO}_{2}$ coatings without zinc, osteogenic gene expression was upregulated in rBMSCs cultivated on zinc-doped $\mathrm{TiO}_{2}$ coatings, and early-stage new bone formation as well as bone contact ratio were increased in vivo [290]. Yu and colleagues further reported increased osteogenic differentiation and mineralized matrix deposition in rat bone marrow-derived pericytes (BM-PCs) and significant promotion of new bone formation around titanium implants in osteopenic rabbits with the application of zinc-modified calcium silicate coatings. Molecular analysis revealed that zinc exerts these actions by regulating the TGF- $\beta$ /Smad signaling pathway, which is pivotal for osteoblastogenesis [298]. Reports on zinc 
in biomedical applications for tissue engineering, especially with regards to the positive impacts on osteoblastogenesis, osteoblast activity and tissue mineralization, are promising for improving implant osseointegration, accelerating bone regeneration and inhibiting biofilm formation.

\subsection{Others}

There are other metals and their corresponding ions which have been demonstrated to have an effect on the bone regeneration process [195]. Webster et al. have shown a higher adsorption of calcium, vitronectin and collagen on yttrium-doped HAp [299]. Others including zirconium and also molybdenum are used in different metal alloys which are used for orthopedic and dental applications [300]. The latter metals are primarily used to achieve specific material properties. There are additional metals that play a role as implant materials, especially titanium, which builds up a very stable oxide layer, and thus, can be considered almost inert under physiological conditions [301]. Nevertheless, for titanium and its alloys, it was shown that released titanium enhanced the release of bone resorbing cytokines from LPS-stimulated monocyte cultures [302]. Long-term in vivo studies in baboons revealed an increased titanium ion concentration in urine as well as enhanced levels in tissues [303]. Nevertheless, no toxic effects were observed up to 8 years after implantation.

\section{Conclusions}

The existing bone substitute materials only provide osteoconductive healing capacities, and most of the newly developed tissue engineering strategies are still not applicable in the daily clinical routine. The presented overview of the physiological mode of action of different metal ions and their influence on the process of bone tissue regeneration has shown that their addition to existing bone substitute materials may alter the inflammation and foreign body response or the onset of bone regeneration as well as material durability. Another important problem is the availability and the cost of suitable bone grafting material for the increasing need of an aging population.

It is obvious that different parameters play an important role in the use or the combination of metals with existing biomaterials. Furthermore, it has been demonstrated that the concentration of the released metal ions plays a crucial role for the bone formation process. Thereby, it would be beneficial to have the ions present in close vicinity of the implanted biomaterial, as bone regeneration should preferably occur directly at the implant site. On the other hand, metals can be incorporated into scaffolds, which support a continuous release to support early induction of osteoblast differentiation, as they can control transcriptional regulators like Runx2 and therefore osteogenesis.

There is still ongoing work investigating specific effects as well as possible synergistic effects of metal ions with other synthetic materials on the differentiation into osteogenic lineage. Therefore, it is necessary to plan and run additional experiments and studies in almost every scientific field to develop the suitable biomaterial patients need.

Acknowledgments: This work was solely funded by the research funds of the authors. The authors would like to thank Mr. Torsten Müller for his excellent assistance.

Author Contributions: Kristina Glenske, Phil Donkiewicz, Alexander Köwitsch, Nada Milosevic-Oljaca, Patrick Rider, Sven Rofall, Jörg Franke, Ole Jung, Ralf Smeets, Reinhard Schnettler, Sabine Wenisch and Mike Barbeck wrote the paper. Reinhard Schnettler, Sabine Wenisch and Mike Barbeck contributed materials.

Conflicts of Interest: The authors declare no conflict of interest.

\section{References}

1. Sakkas, A.; Wilde, F.; Heufelder, M.; Winter, K.; Schramm, A. Autogenous bone grafts in oral implantology-Is it still a "gold standard"? A consecutive review of 279 patients with 456 clinical procedures. Int. J. Implant Dent. 2017, 3, 23. [CrossRef] [PubMed]

2. Sandberg, O.H.; Aspenberg, P. Inter-trabecular bone formation: A specific mechanism for healing of cancellous bone: A narrative review. Acta Orthop. 2016, 87, 459-465. [CrossRef] [PubMed]

3. Garbuz, D.S.; Masri, B.A.; Czitrom, A.A. Biology of allografting. Orthop. Clin. 1998, 29, 199-204. [CrossRef] 
4. Eagan, M.J.; McAllister, D.R. Biology of allograft incorporation. Clin. Sports Med. 2009, 28, $203-214$. [CrossRef] [PubMed]

5. Dimitriou, R.; Mataliotakis, G.I.; Angoules, A.G.; Kanakaris, N.K.; Giannoudis, P.V. Complications following autologous bone graft harvesting from the iliac crest and using the RIA: A systematic review. Injury 2011, 42, S3-S15. [CrossRef] [PubMed]

6. Mano, J.F.; Sousa, R.A.; Boesel, L.F.; Neves, N.M.; Reis, R.L. Bioinert, biodegradable and injectable polymeric matrix composites for hard tissue replacement: State of the art and recent developments. Compos. Sci. Technol. 2004, 64, 789-817. [CrossRef]

7. Kuboyama, N.; Kiba, H.; Arai, K.; Uchida, R.; Tanimoto, Y.; Bhawal, U.K.; Abiko, Y.; Miyamoto, S.; Knight, D.; Asakura, T. Silk fibroin-based scaffolds for bone regeneration. J. Biomed. Mater. Res. Part B Appl. Biomater. 2013, 101, 295-302. [CrossRef] [PubMed]

8. Jung, S.W.; Byun, J.-H.; Oh, S.H.; Kim, T.H.; Park, J.-S.; Rho, G.-J.; Lee, J.H. Multivalent ion-based in situ gelling polysaccharide hydrogel as an injectable bone graft. Carbohydr. Polym. 2018, 180, 216-225. [CrossRef] [PubMed]

9. Dard, M.; Larjava, H. Hydoxyapatite/ $\beta$-tricalcium phosphate biphasic ceramics as regenerative material for the repair of complex bone defects. J. Biomed. Mater. Res. Part B Appl. Biomater. 2017. [CrossRef]

10. Basha, R.Y.; Doble, M. Design of biocomposite materials for bone tissue regeneration. Mater. Sci. Eng. C 2015, 57, 452-463. [CrossRef] [PubMed]

11. Gentile, P.; Chiono, V.; Carmagnola, I.; Hatton, P.V. An overview of poly (lactic-co-glycolic) acid (PLGA)-based biomaterials for bone Tissue Engineering. Int. J. Mol. Sci. 2014, 15, 3640-3659. [CrossRef] [PubMed]

12. Wang, J.; Wu, D.; Zhang, Z.; Li, J.; Shen, Y.; Wang, Z.; Li, Y.; Zhang, Z.-Y.; Sun, J. Biomimetically Ornamented Rapid Prototyping Fabrication of an Apatite-Collagen-Polycaprolactone Composite Construct with Nano-Micro-Macro Hierarchical Structure for Large Bone Defect Treatment. ACS Appl. Mater. Interfaces 2015, 7, 26244-26256. [CrossRef] [PubMed]

13. Miron, R.; Zhang, Y. Osteoinduction: A review of old concepts with new standards. J. Dent. Res. 2012, 91, 736-744. [CrossRef] [PubMed]

14. Gong, T.; Xie, J.; Liao, J.; Zhang, T.; Lin, S.; Lin, Y. Nanomaterials and bone regeneration. Bone Res. 2015, 3, 15029. [CrossRef] [PubMed]

15. Wu, S.; Liu, X.; Yeung, K.W.; Liu, C.; Yang, X. Biomimetic porous scaffolds for bone Tissue Engineering. Mater. Sci. Eng. R Rep. 2014, 80, 1-36. [CrossRef]

16. García-Gareta, E.; Coathup, M.J.; Blunn, G.W. Osteoinduction of bone grafting materials for bone repair and regeneration. Bone 2015, 81, 112-121. [CrossRef] [PubMed]

17. Bae, S.E.; Choi, J.; Joung, Y.K.; Park, K.; Han, D.K. Controlled release of bone morphogenetic protein (BMP)-2 from nanocomplex incorporated on hydroxyapatite-formed titanium surface. J. Control. Release 2012, 160, 676-684. [CrossRef] [PubMed]

18. Wang, J.; Guo, J.; Liu, J.; Wei, L.; Wu, G. BMP-functionalised coatings to promote osteogenesis for orthopaedic implants. Int. J. Mol. Sci. 2014, 15, 10150-10168. [CrossRef] [PubMed]

19. Fernandez-Yague, M.A.; Abbah, S.A.; McNamara, L.; Zeugolis, D.I.; Pandit, A.; Biggs, M.J. Biomimetic approaches in bone Tissue Engineering: Integrating biological and physicomechanical strategies. Adv. Drug Deliv. Rev. 2015, 84, 1-29. [CrossRef] [PubMed]

20. Faruq, O.; Kim, B.; Padalhin, A.R.; Lee, G.H.; Lee, B.-T. A hybrid composite system of biphasic calcium phosphate granules loaded with hyaluronic acid-gelatin hydrogel for bone regeneration. J. Biomater. Appl. 2017, 32, 433-445. [CrossRef] [PubMed]

21. Tanaka, K.; Goto, T.; Miyazaki, T.; Morita, Y.; Kobayashi, S.; Takahashi, T. Apatite-coated hyaluronan for bone regeneration. J. Dent. Res. 2011, 90, 906-911. [CrossRef] [PubMed]

22. Kuttappan, S.; Mathew, D.; Nair, M.B. Biomimetic composite scaffolds containing bioceramics and collagen/gelatin for bone Tissue Engineering-A mini review. Int. J. Biol. Macromol. 2016, 93, 1390-1401. [CrossRef] [PubMed]

23. Lyons, F.G.; Gleeson, J.P.; Partap, S.; Coghlan, K.; O’Brien, F.J. Novel microhydroxyapatite particles in a collagen scaffold: A bioactive bone void filler? Clin. Orthop. Relat. Res. 2014, 472, 1318-1328. [CrossRef] [PubMed] 
24. Förster, Y.; Bernhardt, R.; Hintze, V.; Möller, S.; Schnabelrauch, M.; Scharnweber, D.; Rammelt, S. Collagen/glycosaminoglycan coatings enhance new bone formation in a critical size bone defect-A pilot study in rats. Mater. Sci. Eng. C 2017, 71, 84-92. [CrossRef] [PubMed]

25. Vo, T.N.; Kasper, F.K.; Mikos, A.G. Strategies for controlled delivery of growth factors and cells for bone regeneration. Adv. Drug Deliv. Rev. 2012, 64, 1292-1309. [CrossRef] [PubMed]

26. Boerckel, J.D.; Kolambkar, Y.M.; Dupont, K.M.; Uhrig, B.A.; Phelps, E.A.; Stevens, H.Y.; García, A.J.; Guldberg, R.E. Effects of protein dose and delivery system on BMP-mediated bone regeneration. Biomaterials 2011, 32, 5241-5251. [CrossRef] [PubMed]

27. Haidar, Z.S.; Hamdy, R.C.; Tabrizian, M. Delivery of recombinant bone morphogenetic proteins for bone regeneration and repair. Part B: Delivery systems for BMPs in orthopaedic and craniofacial Tissue Engineering. Biotechnol. Lett. 2009, 31, 1825-1835. [CrossRef] [PubMed]

28. Wozney, J.M. The bone morphogenetic protein family and osteogenesis. Mol. Reprod. Dev. 1992, 32, $160-167$. [CrossRef] [PubMed]

29. Hänseler, P.; Ehrbar, M.; Kruse, A.; Fischer, E.; Schibli, R.; Ghayor, C.; Weber, F.E. Delivery of BMP-2 by two clinically available apatite materials: In vitro and in vivo comparison. J. Biomed. Mater. Res. Part A 2015, 103, 628-638. [CrossRef] [PubMed]

30. Florencio-Silva, R.; de Silva Sasso, G.R.; Sasso-Cerri, E.; Simões, M.J.; Cerri, P.S. Biology of bone tissue: Structure, function, and factors that influence bone cells. BioMed Res. Int. 2015, 2015. [CrossRef] [PubMed]

31. Diomede, F.; Gugliandolo, A.; Scionti, D.; Merciaro, I.; Cavalcanti, M.F.; Mazzon, E.; Trubiani, O. Biotherapeutic Effect of Gingival Stem Cells Conditioned Medium in Bone Tissue Restoration. Int. J. Mol. Sci. 2018, 19, 329. [CrossRef] [PubMed]

32. Bianco, P.; Robey, P.G. Stem cells in Tissue Engineering. Nature 2001, 414, 118. [CrossRef] [PubMed]

33. Kanczler, J.; Oreffo, R. Osteogenesis and angiogenesis: The potential for engineering bone. Eur. Cell Mater. 2008, 15, 100-114. [CrossRef] [PubMed]

34. Santos, M.I.; Unger, R.E.; Sousa, R.A.; Reis, R.L.; Kirkpatrick, C.J. Crosstalk between osteoblasts and endothelial cells co-cultured on a polycaprolactone-starch scaffold and the in vitro development of vascularization. Biomaterials 2009, 30, 4407-4415. [CrossRef] [PubMed]

35. Du, C.; Cui, F.; Zhu, X.; De Groot, K. Three-dimensional nano-HAp/collagen matrix loading with osteogenic cells in organ culture. J. Biomed. Mater. Res. Part A 1999, 44, 407-415. [CrossRef]

36. Mistry, A.S.; Mikos, A.G. Tissue Engineering strategies for bone regeneration. In Regenerative Medicine II; Springer: Berlin/Heidelberg, Germany, 2005; pp. 1-22. [CrossRef]

37. Alexander, K.A.; Chang, M.K.; Maylin, E.R.; Kohler, T.; Müller, R.; Wu, A.C.; Van Rooijen, N.; Sweet, M.J.; Hume, D.A.; Raggatt, L.J. Osteal macrophages promote in vivo intramembranous bone healing in a mouse tibial injury model. J. Bone Miner. Res. 2011, 26, 1517-1532. [CrossRef] [PubMed]

38. Kim, Y.-H.; Furuya, H.; Tabata, Y. Enhancement of bone regeneration by dual release of a macrophage recruitment agent and platelet-rich plasma from gelatin hydrogels. Biomaterials 2014, 35, 214-224. [CrossRef] [PubMed]

39. Yamada, Y.; Ueda, M.; Naiki, T.; Takahashi, M.; Hata, K.-I.; Nagasaka, T. Autogenous injectable bone for regeneration with mesenchymal stem cells and platelet-rich plasma: Tissue-engineered bone regeneration. Tissue Eng. 2004, 10, 955-964. [CrossRef] [PubMed]

40. Weibrich, G.; Hansen, T.; Kleis, W.; Buch, R.; Hitzler, W. Effect of platelet concentration in platelet-rich plasma on peri-implant bone regeneration. Bone 2004, 34, 665-671. [CrossRef] [PubMed]

41. Simonpieri, A.; Del Corso, M.; Vervelle, A.; Jimbo, R.; Inchingolo, F.; Sammartino, G.; Dohan Ehrenfest, D.M. Current knowledge and perspectives for the use of platelet-rich plasma (PRP) and platelet-rich fibrin (PRF) in oral and maxillofacial surgery part 2: Bone graft, implant and reconstructive surgery. Curr. Pharm. Biotechnol. 2012, 13, 1231-1256. [CrossRef] [PubMed]

42. Civinini, R.; Macera, A.; Redl, B.; Innocenti, M. Blood-derived growth factors. Clin. Cases Miner. Bone Metab. 2010, 7, 194.

43. Barrère, F.; van Blitterswijk, C.A.; de Groot, K. Bone regeneration: Molecular and cellular interactions with calcium phosphate ceramics. Int. J. Nanomed. 2006, 1, 317.

44. Inzana, J.A.; Olvera, D.; Fuller, S.M.; Kelly, J.P.; Graeve, O.A.; Schwarz, E.M.; Kates, S.L.; Awad, H.A. 3D printing of composite calcium phosphate and collagen scaffolds for bone regeneration. Biomaterials 2014, 35, 4026-4034. [CrossRef] [PubMed] 
45. Bernhardt, A.; Schamel, M.; Gbureck, U.; Gelinsky, M. Osteoclastic differentiation and resorption is modulated by bioactive metal ions $\mathrm{Co}^{2+}, \mathrm{Cu}^{2+}$ and $\mathrm{Cr}^{3+}$ incorporated into calcium phosphate bone cements. PLoS ONE 2017, 12, e0182109. [CrossRef] [PubMed]

46. Philippart, A.; Gómez-Cerezo, N.; Arcos, D.; Salinas, A.J.; Boccardi, E.; Vallet-Regi, M.; Boccaccini, A.R. Novel ion-doped mesoporous glasses for bone Tissue Engineering: Study of their structural characteristics influenced by the presence of phosphorous oxide. J. Non-Cryst. Solids 2017, 455, 90-97. [CrossRef]

47. Cattalini, J.; Hoppe, A.; Pishbin, F.; Roether, J.; Boccaccini, A.; Lucangioli, S.; Mouriño, V. Novel nanocomposite biomaterials with controlled copper/calcium release capability for bone Tissue Engineering multifunctional scaffolds. J. R. Soc. Interface 2015, 12, 20150509. [CrossRef] [PubMed]

48. Xia, W.; Grandfield, K.; Schwenke, A.; Engqvist, H. Synthesis and release of trace elements from hollow and porous hydroxyapatite spheres. Nanotechnology 2011, 22, 305610. [CrossRef] [PubMed]

49. Maes, C.; Kobayashi, T.; Selig, M.K.; Torrekens, S.; Roth, S.I.; Mackem, S.; Carmeliet, G.; Kronenberg, H.M. Osteoblast precursors, but not mature osteoblasts, move into developing and fractured bones along with invading blood vessels. Dev. Cell 2010, 19, 329-344. [CrossRef] [PubMed]

50. Mastrogiacomo, M.; Scaglione, S.; Martinetti, R.; Dolcini, L.; Beltrame, F.; Cancedda, R.; Quarto, R. Role of scaffold internal structure on in vivo bone formation in macroporous calcium phosphate bioceramics. Biomaterials 2006, 27, 3230-3237. [CrossRef] [PubMed]

51. Woodard, J.R.; Hilldore, A.J.; Lan, S.K.; Park, C.; Morgan, A.W.; Eurell, J.A.C.; Clark, S.G.; Wheeler, M.B.; Jamison, R.D.; Johnson, A.J.W. The mechanical properties and osteoconductivity of hydroxyapatite bone scaffolds with multi-scale porosity. Biomaterials 2007, 28, 45-54. [CrossRef] [PubMed]

52. Blair, H.C.; Larrouture, Q.C.; Li, Y.; Lin, H.; Beer-Stoltz, D.; Liu, L.; Tuan, R.S.; Robinson, L.J.; Schlesinger, P.H.; Nelson, D.J. Osteoblast differentiation and bone matrix formation in vivo and in vitro. Tissue Eng. Part B Rev. 2017, 23, 268-280. [CrossRef] [PubMed]

53. Boyan, B.; Bonewald, L.; Paschalis, E.; Lohmann, C.; Rosser, J.; Cochran, D.; Dean, D.; Schwartz, Z.; Boskey, A. Osteoblast-mediated mineral deposition in culture is dependent on surface microtopography. Calcif. Tissue Int. 2002, 71, 519-529. [CrossRef] [PubMed]

54. Galli, S.; Stocchero, M.; Andersson, M.; Karlsson, J.; He, W.; Lilin, T.; Wennerberg, A.; Jimbo, R. The effect of magnesium on early osseointegration in osteoporotic bone: A histological and gene expression investigation. Osteoporos. Int. 2017, 28, 2195-2205. [CrossRef] [PubMed]

55. Park, J.W.; Kim, Y.J.; Jang, J.H.; Song, H. Osteoblast response to magnesium ion-incorporated nanoporous titanium oxide surfaces. Clin. Oral Implant. Res. 2010, 21, 1278-1287. [CrossRef] [PubMed]

56. Arai, F.; Miyamoto, T.; Ohneda, O.; Inada, T.; Sudo, T.; Brasel, K.; Miyata, T.; Anderson, D.M.; Suda, T. Commitment and differentiation of osteoclast precursor cells by the sequential expression of c-Fms and receptor activator of nuclear factor kB (RANK) receptors. J. Exp. Med. 1999, 190, 1741-1754. [CrossRef] [PubMed]

57. Martin, T.J.; Sims, N.A. Osteoclast-derived activity in the coupling of bone formation to resorption. Trends Mol. Med. 2005, 11, 76-81. [CrossRef] [PubMed]

58. Tanaka, Y.; Nakayamada, S.; Okada, Y. Osteoblasts and osteoclasts in bone remodeling and inflammation. Curr. Drug Targets-Inflamm. Allergy 2005, 4, 325-328. [CrossRef] [PubMed]

59. Wong, B.R.; Josien, R.; Lee, S.Y.; Sauter, B.; Li, H.-L.; Steinman, R.M.; Choi, Y. TRANCE (tumor necrosis factor [TNF]-related activation-induced cytokine), a new TNF family member predominantly expressed in T cells, is a dendritic cell-specific survival factor. J. Exp. Med. 1997, 186, 2075-2080. [CrossRef] [PubMed]

60. Hirano, T. Interleukin 6 and its receptor: Ten years later. Int. Rev. Immunol. 1998, 16, 249-284. [CrossRef] [PubMed]

61. Quinn, J.M.; Gillespie, M.T. Modulation of osteoclast formation. Biochem. Biophys. Res. Commun. 2005, 328, 739-745. [CrossRef] [PubMed]

62. Saran, U.; Piperni, S.G.; Chatterjee, S. Role of angiogenesis in bone repair. Arch. Biochem. Biophys. 2014, 561, 109-117. [CrossRef] [PubMed]

63. Wang, Y.; Wan, C.; Deng, L.; Liu, X.; Cao, X.; Gilbert, S.R.; Bouxsein, M.L.; Faugere, M.-C.; Guldberg, R.E.; Gerstenfeld, L.C. The hypoxia-inducible factor $\alpha$ pathway couples angiogenesis to osteogenesis during skeletal development. J. Clin. Investig. 2007, 117, 1616-1626. [CrossRef] [PubMed] 
64. Schindeler, A.; McDonald, M.M.; Bokko, P.; Little, D.G. Bone remodeling during fracture repair: The cellular picture. In Seminars in Cell E Developmental Biology; Elsevier: Amsterdam, The Netherlands, 2008; pp. 459-466. [CrossRef]

65. Batoon, L.; Millard, S.M.; Raggatt, L.J.; Pettit, A.R. Osteomacs and Bone Regeneration. Curr. Osteoporos. Rep. 2017, 15, 385-395. [CrossRef] [PubMed]

66. Mise-Omata, S.; Alles, N.; Fukazawa, T.; Aoki, K.; Ohya, K.; Jimi, E.; Obata, Y.; Doi, T. NF-кB RELA-deficient bone marrow macrophages fail to support bone formation and to maintain the hematopoietic niche after lethal irradiation and stem cell transplantation. Int. Immunol. 2014, 26, 607-618. [CrossRef] [PubMed]

67. Chang, K.H.; Sengupta, A.; Nayak, R.C.; Duran, A.; Lee, S.J.; Pratt, R.G.; Wellendorf, A.M.; Hill, S.E.; Watkins, M.; Gonzalez-Nieto, D. p62 is required for stem cell/progenitor retention through inhibition of IKK/NF-kB/Ccl4 signaling at the bone marrow macrophage-osteoblast niche. Cell Rep. 2014, 9, 2084-2097. [CrossRef] [PubMed]

68. Coleman, D.; King, R.; Andrade, J. The foreign body reaction: A chronic inflammatory response. J. Biomed. Mater. Res. Part A 1974, 8, 199-211. [CrossRef] [PubMed]

69. Loi, F.; Córdova, L.A.; Pajarinen, J.; Lin, T.-H.; Yao, Z.; Goodman, S.B. Inflammation, fracture and bone repair. Bone 2016, 86, 119-130. [CrossRef] [PubMed]

70. Ghanaati, S.; Barbeck, M.; Detsch, R.; Deisinger, U.; Hilbig, U.; Rausch, V.; Sader, R.; Unger, R.E.; Ziegler, G.; Kirkpatrick, C.J. The chemical composition of synthetic bone substitutes influences tissue reactions in vivo: Histological and histomorphometrical analysis of the cellular inflammatory response to hydroxyapatite, $\beta$-tricalcium phosphate and biphasic calcium phosphate ceramics. Biomed. Mater. 2012, 7, 015005. [CrossRef] [PubMed]

71. Trindade, R.; Albrektsson, T.; Tengvall, P.; Wennerberg, A. Foreign body reaction to biomaterials: On mechanisms for buildup and breakdown of osseointegration. Clin. Implant Dent. Relat. Res. 2016, 18, 192-203. [CrossRef] [PubMed]

72. Martin, P.; Leibovich, S.J. Inflammatory cells during wound repair: The good, the bad and the ugly. Trends Cell Biol. 2005, 15, 599-607. [CrossRef] [PubMed]

73. Mantovani, A.; Sica, A.; Sozzani, S.; Allavena, P.; Vecchi, A.; Locati, M. The chemokine system in diverse forms of macrophage activation and polarization. Trends Immunol. 2004, 25, 677-686. [CrossRef] [PubMed]

74. Barbeck, M.; Booms, P.; Unger, R.; Hoffmann, V.; Sader, R.; Kirkpatrick, C.J.; Ghanaati, S. Multinucleated giant cells in the implant bed of bone substitutes are foreign body giant cells- $\mathrm{New}$ insights into the material-mediated healing process. J. Biomed. Mater. Res. Part A 2017, 105, 1105-1111. [CrossRef] [PubMed]

75. Anderson, J.M. Multinucleated giant cells. Curr. Opin. Hematol. 2000, 7, 40-47. [CrossRef] [PubMed]

76. Mountziaris, P.M.; Mikos, A.G. Modulation of the inflammatory response for enhanced bone tissue regeneration. Tissue Eng. Part B Rev. 2008, 14, 179-186. [CrossRef] [PubMed]

77. Sussman, E.M.; Halpin, M.C.; Muster, J.; Moon, R.T.; Ratner, B.D. Porous implants modulate healing and induce shifts in local macrophage polarization in the foreign body reaction. Ann. Biomed. Eng. 2014, 42, 1508-1516. [CrossRef] [PubMed]

78. Ahmadzadeh, E.; Talebnia, F.; Tabatabaei, M.; Ahmadzadeh, H.; Mostaghaci, B. Osteoconductive composite graft based on bacterial synthesized hydroxyapatite nanoparticles doped with different ions: From synthesis to in vivo studies. Nanomed. Nanotechnol. Biol. Med. 2016, 12, 1387-1395. [CrossRef] [PubMed]

79. Exley, C. Human exposure to aluminium. Environ. Sci. Process. Impacts 2013, 15, 1807-1816. [CrossRef] [PubMed]

80. Priyadarshi, A.; Shapiro, J.I. Hematology: Issues in the dialysis patient: Erythropoietin resistance in the treatment of the anemia of chronic renal failure. Semin. Dial. 2006, 19, 273-278. [CrossRef] [PubMed]

81. Kawahara, M. Effects of aluminum on the nervous system and its possible link with neurodegenerative diseases. J. Alzheimer's Dis. 2005, 8, 171-182. [CrossRef]

82. Aaseth, J.; Boivin, G.; Andersen, O. Osteoporosis and trace elements-An overview. J. Trace Elem. Med. Biol. 2012, 26, 149-152. [CrossRef] [PubMed]

83. Lukiw, W.J.; Percy, M.E.; Kruck, T.P. Nanomolar aluminum induces pro-inflammatory and pro-apoptotic gene expression in human brain cells in primary culture. J. Inorg. Biochem. 2005, 99, 1895-1898. [CrossRef] [PubMed] 
84. Gomez-Alonso, C.; Menendez-Rodriguez, P.; Virgos-Soriano, M.; Fernandez-Martin, J.; Fernandez-Coto, M.; Cannata-Andia, J. Aluminum-induced osteogenesis in osteopenic rats with normal renal function. Calcif. Tissue Int. 1999, 64, 534-541. [CrossRef] [PubMed]

85. Quarles, L.; Gitelman, H.; Drezner, M. Induction of de novo bone formation in the beagle. A novel effect of aluminum. J. Clin. Investig. 1988, 81, 1056-1066. [CrossRef] [PubMed]

86. Li, X.; Han, Y.; Guan, Y.; Zhang, L.; Bai, C.; Li, Y. Aluminum induces osteoblast apoptosis through the oxidative stress-mediated JNK signaling pathway. Biol. Trace Elem. Res. 2012, 150, 502-508. [CrossRef] [PubMed]

87. Kidder, L.S.; Klein, G.L.; Gundberg, C.M.; Seitz, P.K.; Rubin, N.H.; Simmons, D.J. Effects of aluminum on rat bone cell populations. Calcif. Tissue Int. 1993, 53, 357-361. [CrossRef] [PubMed]

88. Li, X.; Hu, C.; Zhu, Y.; Sun, H.; Li, Y.; Zhang, Z. Effects of aluminum exposure on bone mineral density, mineral, and trace elements in rats. Biol. Trace Elem. Res. 2011, 143, 378-385. [CrossRef] [PubMed]

89. Piconi, C.; Condo, S.G.; Kosmač, T. Alumina-and zirconia-based ceramics for load-bearing applications. In Advanced Ceramics for Dentistry; Elsevier: Amsterdam, The Netherlands, 2014; pp. 219-253.

90. Zhang, J.; Liu, W.; Schnitzler, V.; Tancret, F.; Bouler, J.-M. Calcium phosphate cements for bone substitution: Chemistry, handling and mechanical properties. Acta Biomater. 2014, 10, 1035-1049. [CrossRef] [PubMed]

91. Prati, C.; Gandolfi, M.G. Calcium silicate bioactive cements: Biological perspectives and clinical applications. Dent. Mater. 2015, 31, 351-370. [CrossRef] [PubMed]

92. Eliaz, N.; Metoki, N. Calcium phosphate bioceramics: A review of their history, structure, properties, coating technologies and biomedical applications. Materials 2017, 10, 334. [CrossRef] [PubMed]

93. González-Vázquez, A.; Planell, J.A.; Engel, E. Extracellular calcium and CaSR drive osteoinduction in mesenchymal stromal cells. Acta Biomater. 2014, 10, 2824-2833. [CrossRef] [PubMed]

94. Silver, I.; Murrills, R.; Etherington, D. Microelectrode studies on the acid microenvironment beneath adherent macrophages and osteoclasts. Exp. Cell Res. 1988, 175, 266-276. [CrossRef]

95. Maeno, S.; Niki, Y.; Matsumoto, H.; Morioka, H.; Yatabe, T.; Funayama, A.; Toyama, Y.; Taguchi, T.; Tanaka, J. The effect of calcium ion concentration on osteoblast viability, proliferation and differentiation in monolayer and 3D culture. Biomaterials 2005, 26, 4847-4855. [CrossRef] [PubMed]

96. Barradas, A.M.; Fernandes, H.A.; Groen, N.; Chai, Y.C.; Schrooten, J.; van de Peppel, J.; van Leeuwen, J.P.; van Blitterswijk, C.A.; de Boer, J. A calcium-induced signaling cascade leading to osteogenic differentiation of human bone marrow-derived mesenchymal stromal cells. Biomaterials 2012, 33, 3205-3215. [CrossRef] [PubMed]

97. Wagner, A.-S.; Glenske, K.; Henß, A.; Kruppke, B.; Rößler, S.; Hanke, T.; Moritz, A.; Rohnke, M.; Kressin, M.; Arnhold, S. Cell behavior of human mesenchymal stromal cells in response to silica/collagen based xerogels and calcium deficient culture conditions. Biomed. Mater. 2017, 12, 045003. [CrossRef] [PubMed]

98. Wagner, A.-S.; Glenske, K.; Wolf, V.; Fietz, D.; Mazurek, S.; Hanke, T.; Moritz, A.; Arnhold, S.; Wenisch, S. Osteogenic differentiation capacity of human mesenchymal stromal cells in response to extracellular calcium with special regard to connexin 43. Ann. Anat. Anat. Anz. 2017, 209, 18-24. [CrossRef] [PubMed]

99. Ye, J.; Ai, W.; Zhang, F.; Zhu, X.; Shu, G.; Wang, L.; Gao, P.; Xi, Q.; Zhang, Y.; Jiang, Q. Enhanced proliferation of porcine bone marrow mesenchymal stem cells induced by extracellular calcium is associated with the activation of the calcium-sensing receptor and ERK signaling pathway. Stem Cell Int. 2016, 2016. [CrossRef] [PubMed]

100. Huang, Z.; Cheng, S.-L.; Slatopolsky, E. Sustained activation of the extracellular signal-regulated kinase pathway is required for extracellular calcium stimulation of human osteoblast proliferation. J. Biol. Chem. 2001, 276, 21351-21358. [CrossRef] [PubMed]

101. Dvorak, M.M.; Siddiqua, A.; Ward, D.T.; Carter, D.H.; Dallas, S.L.; Nemeth, E.F.; Riccardi, D. Physiological changes in extracellular calcium concentration directly control osteoblast function in the absence of calciotropic hormones. Proc. Natl. Acad. Sci. USA 2004, 101, 5140-5145. [CrossRef] [PubMed]

102. Brown, E.M.; MacLeod, R.J. Extracellular calcium sensing and extracellular calcium signaling. Physiol. Rev. 2001, 81, 239-297. [CrossRef] [PubMed]

103. Olszak, I.T.; Poznansky, M.C.; Evans, R.H.; Olson, D.; Kos, C.; Pollak, M.R.; Brown, E.M.; Scadden, D.T. Extracellular calcium elicits a chemokinetic response from monocytes in vitro and in vivo. J. Clin. Investig. 2000, 105, 1299-1305. [CrossRef] [PubMed] 
104. Glenske, K.; Wagner, A.-S.; Hanke, T.; Cavalcanti-Adam, E.A.; Heinemann, S.; Heinemann, C.; Kruppke, B.; Arnhold, S.; Moritz, A.; Schwab, E.H. Bioactivity of xerogels as modulators of osteoclastogenesis mediated by connexin 43. Biomaterials 2014, 35, 1487-1495. [CrossRef] [PubMed]

105. Yamauchi, M.; Yamaguchi, T.; Kaji, H.; Sugimoto, T.; Chihara, K. Involvement of calcium-sensing receptor in osteoblastic differentiation of mouse MC3T3-E1 cells. Am. J. Physiol.-Endocrinol. Metab. 2005, 288, E608-E616. [CrossRef] [PubMed]

106. Hu, F.; Pan, L.; Zhang, K.; Xing, F.; Wang, X.; Lee, I.; Zhang, X.; Xu, J. Elevation of extracellular Ca ${ }^{2+}$ induces store-operated calcium entry via calcium-sensing receptors: A pathway contributes to the proliferation of osteoblasts. PLoS ONE 2014, 9, e107217. [CrossRef] [PubMed]

107. Zhang, W.; Liu, H.T. MAPK signal pathways in the regulation of cell proliferation in mammalian cells. Cell Res. 2002, 12, 9. [CrossRef] [PubMed]

108. Parekh, A.B.; Putney, J.W., Jr. Store-operated calcium channels. Physiol. Rev. 2005, 85, 757-810. [CrossRef] [PubMed]

109. Wen, L.; Wang, Y.; Wang, H.; Kong, L.; Zhang, L.; Chen, X.; Ding, Y. L-type calcium channels play a crucial role in the proliferation and osteogenic differentiation of bone marrow mesenchymal stem cells. Biochem. Biophys. Res. Commun. 2012, 424, 439-445. [CrossRef] [PubMed]

110. Heinemann, S.; Heinemann, C.; Wenisch, S.; Alt, V.; Worch, H.; Hanke, T. Calcium phosphate phases integrated in silica/collagen nanocomposite xerogels enhance the bioactivity and ultimately manipulate the osteoblast/osteoclast ratio in a human co-culture model. Acta Biomater. 2013, 9, 4878-4888. [CrossRef] [PubMed]

111. Hoppe, A.; Güldal, N.S.; Boccaccini, A.R. A review of the biological response to ionic dissolution products from bioactive glasses and glass-ceramics. Biomaterials 2011, 32, 2757-2774. [CrossRef] [PubMed]

112. Beck, G.R. Inorganic phosphate as a signaling molecule in osteoblast differentiation. J. Cell. Biochem. 2003, 90, 234-243. [CrossRef] [PubMed]

113. Shih, Y.-R.V.; Hwang, Y.; Phadke, A.; Kang, H.; Hwang, N.S.; Caro, E.J.; Nguyen, S.; Siu, M.; Theodorakis, E.A.; Gianneschi, N.C.; et al. Calcium phosphate-bearing matrices induce osteogenic differentiation of stem cells through adenosine signaling. Proc. Natl. Acad. Sci. USA 2014, 111, 990-995. [CrossRef] [PubMed]

114. Hoffman, N.J.; Penque, B.A.; Habegger, K.M.; Sealls, W.; Tackett, L.; Elmendorf, J.S. Chromium enhances insulin responsiveness via AMPK. J. Nutr. Biochem. 2014, 25, 565-572. [CrossRef] [PubMed]

115. EFSA. Scientific Opinion on Dietary Reference Values for Chromium. EFSA J. 2014, 12, 3845. [CrossRef]

116. Raghunathan, V.K.; Tettey, J.N.; Ellis, E.M.; Grant, M.H. Comparative chronic in vitro toxicity of hexavalent chromium to osteoblasts and monocytes. J. Biomed. Mater. Res. Part A 2009, 88, 543-550. [CrossRef] [PubMed]

117. Ning, J.; Henderson, C.; Grant, M. The cytotoxicity of chromium in osteoblasts: Effects on macromolecular synthesis. J. Mater. Sci. Mater. Med. 2002, 13, 47-52. [CrossRef] [PubMed]

118. Schröck, K.; Lutz, J.; Mändl, S.; Hacker, M.C.; Kamprad, M.; Schulz-Siegmund, M. Co(II)-mediated effects of plain and plasma immersion ion implanted cobalt-chromium alloys on the osteogenic differentiation of human mesenchymal stem cells. J. Orthop. Res. 2015, 33, 325-333. [CrossRef] [PubMed]

119. Drynda, S.; Drynda, A.; Kekow, J.; Lohmann, C. AB0074 Influence of Cobalt and Chromium ions on TGF-BETA Expression and Mineralization of Bone Forming Cells IN-VITRO; BMJ Publishing Group Ltd.: London, UK, 2017. [CrossRef]

120. Fan, W.; Crawford, R.; Xiao, Y. Enhancing in vivo vascularized bone formation by cobalt chloride-treated bone marrow stromal cells in a tissue engineered periosteum model. Biomaterials 2010, 31, 3580-3589. [CrossRef] [PubMed]

121. Yuan, Y.; Hilliard, G.; Ferguson, T.; Millhorn, D.E. Cobalt inhibits the interaction between hypoxia-inducible factor- $\alpha$ and von Hippel-Lindau protein by direct binding to hypoxia-inducible factor- $\alpha$. J. Biol. Chem. 2003, 278, 15911-15916. [CrossRef] [PubMed]

122. Tanaka, T.; Kojima, I.; Ohse, T.; Ingelfinger, J.R.; Adler, S.; Fujita, T.; Nangaku, M. Cobalt promotes angiogenesis via hypoxia-inducible factor and protects tubulointerstitium in the remnant kidney model. Lab. Investig. 2005, 85, 1292. [CrossRef] [PubMed]

123. Birgani, Z.T.; Fennema, E.; Gijbels, M.J.; de Boer, J.; van Blitterswijk, C.A.; Habibovic, P. Stimulatory effect of cobalt ions incorporated into calcium phosphate coatings on neovascularization in an in vivo intramuscular model in goats. Acta Biomater. 2016, 36, 267-276. [CrossRef] [PubMed] 
124. Ignjatović, N.; Ajduković, Z.; Savić, V.; Najman, S.; Mihailović, D.; Vasiljević, P.; Stojanović, Z.; Uskoković, V.; Uskoković, D. Nanoparticles of cobalt-substituted hydroxyapatite in regeneration of mandibular osteoporotic bones. J. Mater. Sci. Mater. Med. 2013, 24, 343-354. [CrossRef] [PubMed]

125. Perez, R.A.; Kim, J.-H.; Buitrago, J.O.; Wall, I.B.; Kim, H.-W. Novel therapeutic core-shell hydrogel scaffolds with sequential delivery of cobalt and bone morphogenetic protein-2 for synergistic bone regeneration. Acta Biomater. 2015, 23, 295-308. [CrossRef] [PubMed]

126. Kargozar, S.; Lotfibakhshaiesh, N.; Ai, J.; Mozafari, M.; Milan, P.B.; Hamzehlou, S.; Barati, M.; Baino, F.; Hill, R.G.; Joghataei, M.T. Strontium-and cobalt-substituted bioactive glasses seeded with human umbilical cord perivascular cells to promote bone regeneration via enhanced osteogenic and angiogenic activities. Acta Biomater. 2017, 58, 502-514. [CrossRef] [PubMed]

127. Festa, R.A.; Thiele, D.J. Copper: An essential metal in biology. Curr. Biol. 2011, 21, R877-R883. [CrossRef] [PubMed]

128. Strain, J. A reassessment of diet and osteoporosis-Possible role for copper. Med. Hypotheses 1988, 27, 333-338. [CrossRef]

129. Strause, L.G.; Hegenauer, J.; Saltman, P.; Cone, R.; Resnick, D. Effects of long-term dietary manganese and copper deficiency on rat skeleton. J. Nutr. 1986, 116, 135-141. [CrossRef] [PubMed]

130. Ziche, M.; Jones, J.; Gullino, P.M. Role of prostaglandin E1 and copper in angiogenesis. J. Natl. Cancer Inst. 1982, 69, 475-482. [CrossRef] [PubMed]

131. Dan, Z.; Ni, H.; Xu, B.; Xiong, J.; Xiong, P. Microstructure and antibacterial properties of AISI 420 stainless steel implanted by copper ions. Thin Solid films 2005, 492, 93-100. [CrossRef]

132. Gérard, C.; Bordeleau, L.-J.; Barralet, J.; Doillon, C.J. The stimulation of angiogenesis and collagen deposition by copper. Biomaterials 2010, 31, 824-831. [CrossRef] [PubMed]

133. Kong, N.; Lin, K.; Li, H.; Chang, J. Synergy effects of copper and silicon ions on stimulation of vascularization by copper-doped calcium silicate. J. Mater. Chem. B 2014, 2, 1100-1110. [CrossRef]

134. Wu, C.; Zhou, Y.; Xu, M.; Han, P.; Chen, L.; Chang, J.; Xiao, Y. Copper-containing mesoporous bioactive glass scaffolds with multifunctional properties of angiogenesis capacity, osteostimulation and antibacterial activity. Biomaterials 2013, 34, 422-433. [CrossRef] [PubMed]

135. Rodríguez, J.P.; Rios, S.; Gonzalez, M. Modulation of the proliferation and differentiation of human mesenchymal stem cells by copper. J. Cell. Biochem. 2002, 85, 92-100. [CrossRef] [PubMed]

136. Li, S.; Wang, M.; Chen, X.; Li, S.F.; Li-Ling, J.; Xie, H.Q. Inhibition of osteogenic differentiation of mesenchymal stem cells by copper supplementation. Cell Prolif. 2014, 47, 81-90. [CrossRef] [PubMed]

137. Lin, Y.; Xiao, W.; Bal, B.S.; Rahaman, M.N. Effect of copper-doped silicate 13-93 bioactive glass scaffolds on the response of MC3T3-E1 cells in vitro and on bone regeneration and angiogenesis in rat calvarial defects in vivo. Mater. Sci. Eng. C 2016, 67, 440-452. [CrossRef] [PubMed]

138. D’Mello, S.; Elangovan, S.; Hong, L.; Ross, R.D.; Sumner, D.R.; Salem, A.K. Incorporation of copper into chitosan scaffolds promotes bone regeneration in rat calvarial defects. J. Biomed. Mater. Res. Part B Appl. Biomater. 2015, 103, 1044-1049. [CrossRef] [PubMed]

139. Warrell, R.P., Jr.; Alcock, N.W.; Bockman, R.S. Gallium nitrate inhibits accelerated bone turnover in patients with bone metastases. J. Clin. Oncol. 1987, 5, 292-298. [CrossRef] [PubMed]

140. Ross-Gillespie, A.; Weigert, M.; Brown, S.P.; Kümmerli, R. Gallium-mediated siderophore quenching as an evolutionarily robust antibacterial treatment. Evol. Med. Public Health 2014, 2014, 18-29. [CrossRef] [PubMed]

141. Zhu, Y.; Qiu, Y.; Chen, R.; Liao, L. The Inhibition of Escherichia Coli Biofilm Formation by Gallium Nitrate-Modified Titanium. J. Nanosci. Nanotechnol. 2015, 15, 5605-5609. [CrossRef] [PubMed]

142. Cochis, A.; Azzimonti, B.; Della Valle, C.; Chiesa, R.; Arciola, C.R.; Rimondini, L. Biofilm formation on titanium implants counteracted by grafting gallium and silver ions. J. Biomed. Mater. Res. Part A 2015, 103, 1176-1187. [CrossRef] [PubMed]

143. Verron, E.; Masson, M.; Khoshniat, S.; Duplomb, L.; Wittrant, Y.; Baud'huin, M.; Badran, Z.; Bujoli, B.; Janvier, P.; Scimeca, J.C.; et al. Gallium modulates osteoclastic bone resorption in vitro without affecting osteoblasts. Br. J. Pharmacol. 2010, 159, 1681-1692. [CrossRef] [PubMed]

144. Mellier, C.; Fayon, F.; Boukhechba, F.; Verron, E.; LeFerrec, M.; Montavon, G.; Lesoeur, J.; Schnitzler, V.; Massiot, D.; Janvier, P.; et al. Design and properties of novel gallium-doped injectable apatitic cements. Acta Biomater. 2015, 24, 322-332. [CrossRef] [PubMed] 
145. Strazic Geljic, I.; Melis, N.; Boukhechba, F.; Schaub, S.; Mellier, C.; Janvier, P.; Laugier, J.P.; Bouler, J.M.; Verron, E.; Scimeca, J.C. Gallium enhances reconstructive properties of a calcium phosphate bone biomaterial. J. Tissue Eng. Regener. Med. 2017. [CrossRef] [PubMed]

146. Beard, J.L. Iron biology in immune function, muscle metabolism and neuronal functioning. J. Nutr. 2001, 131, 568S-580S. [CrossRef] [PubMed]

147. Abbaspour, N.; Hurrell, R.; Kelishadi, R. Review on iron and its importance for human health. J. Res. Med. Sci. 2014, 19, 164. [PubMed]

148. Lieu, P.T.; Heiskala, M.; Peterson, P.A.; Yang, Y. The roles of iron in health and disease. Mol. Asp. Med. 2001, 22, 1-87. [CrossRef]

149. Andrews, N.C. Disorders of iron metabolism. N. Engl. J. Med. 1999, 341, 1986-1995. [CrossRef] [PubMed]

150. Conrad, M.E.; Umbreit, J.N.; Moore, E.G. Iron absorption and transport. Am. J. Med. Sci. 1999, 318, $213-229$. [CrossRef]

151. Ponka, P. Cell biology of heme. Am. J. Med. Sci. 1999, 318, 241-256. [CrossRef]

152. Lill, R. Function and biogenesis of iron-sulphur proteins. Nature 2009, 460, 831. [CrossRef] [PubMed]

153. Ponka, P.; Beaumont, C.; Richardson, D.R. Function and regulation of transferrin and ferritin. Semin. Hematol. 1998, 35, 35-54. [PubMed]

154. Abboud, S.; Haile, D.J. A novel mammalian iron-regulated protein involved in intracellular iron metabolism. J. Biol. Chem. 2000, 275, 19906-19912. [CrossRef] [PubMed]

155. Aravind, L.; Koonin, E.V. The DNA-repair protein AlkB, EGL-9, and leprecan define new families of 2-oxoglutarate-and iron-dependent dioxygenases. Genome Biol. 2001, 2, research0007-1. [CrossRef]

156. Eaton, J.W.; Qian, M. Molecular bases of cellular iron toxicity12. Free Radic. Biol. Med. 2002, 32, 833-840. [CrossRef]

157. Diamond, T.; Stiel, D.; Posen, S. Osteoporosis in hemochromatosis: Iron excess, gonadal deficiency, or other factors? Ann. Intern. Med. 1989, 110, 430-436. [CrossRef] [PubMed]

158. Zarjou, A.; Jeney, V.; Arosio, P.; Poli, M.; Zavaczki, E.; Balla, G.; Balla, J. Ferritin ferroxidase activity: A potent inhibitor of osteogenesis. J. Bone Miner. Res. 2010, 25, 164-172. [CrossRef] [PubMed]

159. Weinberg, E.D. Iron loading: A risk factor for osteoporosis. Biometals 2006, 19, 633-635. [CrossRef] [PubMed]

160. Weinberg, E. Role of iron in osteoporosis. Pediatr. Endocrinol. Rev. PER 2008, 6, 81-85. [PubMed]

161. Chen, B.; Yan, Y.-L.; Liu, C.; Bo, L.; Li, G.-F.; Wang, H.; Xu, Y.-J. Therapeutic effect of deferoxamine on iron overload-induced inhibition of osteogenesis in a zebrafish model. Calcif. Tissue Int. 2014, 94, 353-360. [CrossRef] [PubMed]

162. Jiang, Y.; Yan, Y.; Wang, X.; Zhu, G.; Xu, Y.-J. Hepcidin inhibition on the effect of osteogenesis in zebrafish. Biochem. Biophys. Res. Commun. 2016, 476, 1-6. [CrossRef] [PubMed]

163. Balogh, E.; Tolnai, E.; Nagy, B., Jr.; Nagy, B.; Balla, G.; Balla, J.; Jeney, V. Iron overload inhibits osteogenic commitment and differentiation of mesenchymal stem cells via the induction of ferritin. Biochim. Biophys. Acta Mol. Basis Dis. 2016, 1862, 1640-1649. [CrossRef] [PubMed]

164. Jia, P.; Xu, Y.J.; Zhang, Z.L.; Li, K.; Li, B.; Zhang, W.; Yang, H. Ferric ion could facilitate osteoclast differentiation and bone resorption through the production of reactive oxygen species. J. Orthop. Res. 2012, 30, 1843-1852. [CrossRef] [PubMed]

165. Wang, Q.; Chen, B.; Cao, M.; Sun, J.; Wu, H.; Zhao, P.; Xing, J.; Yang, Y.; Zhang, X.; Ji, M.; et al. Response of MAPK pathway to iron oxide nanoparticles in vitro treatment promotes osteogenic differentiation of hBMSCs. Biomaterials 2016, 86, 11-20. [CrossRef] [PubMed]

166. Zhao, G.-Y.; Zhao, L.-P.; He, Y.-F.; Li, G.-F.; Gao, C.; Li, K.; Xu, Y.-J. A comparison of the biological activities of human osteoblast hFOB1. 19 between iron excess and iron deficiency. Biol. Trace Elem. Res. 2012, 150, 487-495. [CrossRef] [PubMed]

167. Jeney, V. Clinical impact and cellular mechanisms of iron overload-associated bone loss. Front. Pharmacol. 2017, 8, 77. [CrossRef] [PubMed]

168. Geddes, J.R.; Burgess, S.; Hawton, K.; Jamison, K.; Goodwin, G.M. Long-term lithium therapy for bipolar disorder: Systematic review and meta-analysis of randomized controlled trials. Am. J. Psychiatry 2004, 161, 217-222. [CrossRef] [PubMed]

169. Su, H.; Chu, T.-H.; Wu, W. Lithium enhances proliferation and neuronal differentiation of neural progenitor cells in vitro and after transplantation into the adult rat spinal cord. Exp. Neurol. 2007, 206, 296-307. [CrossRef] [PubMed] 
170. Mora, A.; Sabio, G.; Risco, A.M.A.; Cuenda, A.; Alonso, J.C.; Soler, G.; Centeno, F. Lithium blocks the PKB and GSK3 dephosphorylation induced by ceramide through protein phosphatase-2A. Cell. Signal. 2002, 14, 557-562. [CrossRef]

171. De Boer, J.; Wang, H.J.; Van Blitterswijk, C. Effects of Wnt signaling on proliferation and differentiation of human mesenchymal stem cells. Tissue Eng. 2004, 10, 393-401. [CrossRef] [PubMed]

172. Zhu, Z.; Yin, J.; Guan, J.; Hu, B.; Niu, X.; Jin, D.; Wang, Y.; Zhang, C. Lithium stimulates human bone marrow derived mesenchymal stem cell proliferation through GSK-3 $\beta$-dependent $\beta$-catenin/Wnt pathway activation. FEBS J. 2014, 281, 5371-5389. [CrossRef] [PubMed]

173. Hartmann, C. A Wnt canon orchestrating osteoblastogenesis. Trends Cell Biol. 2006, 16, 151-158. [CrossRef] [PubMed]

174. Vestergaard, P.; Rejnmark, L.; Mosekilde, L. Reduced relative risk of fractures among users of lithium. Calcif. Tissue Int. 2005, 77, 1-8. [CrossRef] [PubMed]

175. Zamani, A.; Omrani, G.R.; Nasab, M.M. Lithium's effect on bone mineral density. Bone 2009, 44, 331-334. [CrossRef] [PubMed]

176. Satija, N.K.; Sharma, D.; Afrin, F.; Tripathi, R.P.; Gangenahalli, G. High throughput transcriptome profiling of lithium stimulated human mesenchymal stem cells reveals priming towards osteoblastic lineage. PLoS ONE 2013, 8, e55769. [CrossRef] [PubMed]

177. Moon, J.S.; Ko, H.M.; Park, J.I.; Kim, J.H.; Kim, S.H.; Kim, M.S. Inhibition of human mesenchymal stem cell proliferation via Wnt signaling activation. J. Cell. Biochem. 2018. [CrossRef] [PubMed]

178. Tang, L.; Chen, Y.; Pei, F.; Zhang, H. Lithium chloride modulates adipogenesis and osteogenesis of human bone marrow-derived mesenchymal stem cells. Cell. Physiol. Biochem. 2015, 37, 143-152. [CrossRef] [PubMed]

179. Wang, X.; Zhu, S.; Jiang, X.; Li, Y.; Song, D.; Hu, J. Systemic administration of lithium improves distracted bone regeneration in rats. Calcif. Tissue Int. 2015, 96, 534-540. [CrossRef] [PubMed]

180. Da Silva, J.G.; Babb, R.; Salzlechner, C.; Sharpe, P.T.; Brauer, D.S.; Gentleman, E. Optimisation of lithium-substituted bioactive glasses to tailor cell response for hard tissue repair. J. Mater. Sci. 2017, 52, 8832-8844. [CrossRef] [PubMed]

181. Cai, Y.; Guo, L.; Shen, H.; An, X.; Jiang, H.; Ji, F.; Niu, Y. Degradability, bioactivity, and osteogenesis of biocomposite scaffolds of lithium-containing mesoporous bioglass and mPEG-PLGA-b-PLL copolymer. Int. J. Nanomed. 2015, 10, 4125. [CrossRef]

182. Wang, Y.; Yang, X.; Gu, Z.; Qin, H.; Li, L.; Liu, J.; Yu, X. In vitro study on the degradation of lithium-doped hydroxyapatite for bone Tissue Engineering scaffold. Mater. Sci. Eng. C 2016, 66, 185-192. [CrossRef] [PubMed]

183. Li, L.; Peng, X.; Qin, Y.; Wang, R.; Tang, J.; Cui, X.; Wang, T.; Liu, W.; Pan, H.; Li, B. Acceleration of bone regeneration by activating $\mathrm{Wnt} / \beta$-catenin signalling pathway via lithium released from lithium chloride/calcium phosphate cement in osteoporosis. Sci. Rep. 2017, 7, 45204. [CrossRef] [PubMed]

184. Jahnen-Dechent, W.; Ketteler, M. Magnesium basics. Clin. Kidney J. 2012, 5 (Suppl. 1), i3-i14. [CrossRef] [PubMed]

185. Okuma, T. Magnesium and Bone Strength; Elsevier: Amsterdam, The Netherlands, 2001.

186. Arnaud, M.J. Update on the assessment of magnesium status. Br. J. Nutr. 2008, 99, S24-S36. [CrossRef] [PubMed]

187. Vormann, J. Magnesium: Nutrition and metabolism. Mol. Asp. Med. 2003, 24, 27-37. [CrossRef]

188. Weng, L.; Webster, T.J. Nanostructured magnesium has fewer detrimental effects on osteoblast function. Int. J. Nanomed. 2013, 8, 1773. [CrossRef]

189. Castiglioni, S.; Leidi, M.; Carpanese, E.; Maier, J.A. Extracellular magnesium and in vitro cell differentiation: Different behaviour of different cells. Magnes. Res. 2013, 26, 24-31. [CrossRef] [PubMed]

190. Welch, A.A.; Skinner, J.; Hickson, M. Dietary Magnesium May Be Protective for Aging of Bone and Skeletal Muscle in Middle and Younger Older Age Men and Women: Cross-Sectional Findings from the UK Biobank Cohort. Nutrients 2017, 9, 1189. [CrossRef] [PubMed]

191. Belluci, M.M.; Giro, G.; del Barrio, R.A.L.; Pereira, R.M.R.; Marcantonio, E.; Orrico, S.R.P. Effects of magnesium intake deficiency on bone metabolism and bone tissue around osseointegrated implants. Clin. Oral Implant. Res. 2011, 22, 716-721. [CrossRef] [PubMed] 
192. Rude, R.; Gruber, H.; Norton, H.; Wei, L.; Frausto, A.; Kilburn, J. Reduction of dietary magnesium by only $50 \%$ in the rat disrupts bone and mineral metabolism. Osteoporos. Int. 2006, 17, 1022-1032. [CrossRef] [PubMed]

193. Bae, Y.J.; Kim, M.-H. Calcium and magnesium supplementation improves serum OPG/RANKL in calcium-deficient ovariectomized rats. Calcif. Tissue Int. 2010, 87, 365-372. [CrossRef] [PubMed]

194. Chen, X.; Liao, X.; Huang, Z.; You, P.; Chen, C.; Kang, Y.; Yin, G. Synthesis and characterization of novel multiphase bioactive glass-ceramics in the $\mathrm{CaO}-\mathrm{MgO}-\mathrm{SiO}_{2}$ system. J. Biomed. Mater. Res. Part B Appl. Biomater. 2010, 93, 194-202. [CrossRef] [PubMed]

195. Mouriño, V.; Cattalini, J.P.; Boccaccini, A.R. Metallic ions as therapeutic agents in Tissue Engineering scaffolds: An overview of their biological applications and strategies for new developments. J. R. Soc. Interface 2011. [CrossRef] [PubMed]

196. Hussain, A.; Bessho, K.; Takahashi, K.; Tabata, Y. Magnesium calcium phosphate as a novel component enhances mechanical/physical properties of gelatin scaffold and osteogenic differentiation of bone marrow mesenchymal stem cells. Tissue Eng. Part A 2011, 18, 768-774. [CrossRef] [PubMed]

197. Yoshizawa, S.; Chaya, A.; Verdelis, K.; Bilodeau, E.A.; Sfeir, C. An in vivo model to assess magnesium alloys and their biological effect on human bone marrow stromal cells. Acta Biomater. 2015, 28, 234-239. [CrossRef] [PubMed]

198. Witte, F.; Kaese, V.; Haferkamp, H.; Switzer, E.; Meyer-Lindenberg, A.; Wirth, C.; Windhagen, H. In vivo corrosion of four magnesium alloys and the associated bone response. Biomaterials 2005, 26, 3557-3563. [CrossRef] [PubMed]

199. Witte, F.; Ulrich, H.; Palm, C.; Willbold, E. Biodegradable magnesium scaffolds: Part II: Peri-implant bone remodeling. J. Biomed. Mater. Res. Part A 2007, 81, 757-765. [CrossRef] [PubMed]

200. Galli, S.; Naito, Y.; Karlsson, J.; He, W.; Andersson, M.; Wennerberg, A.; Jimbo, R. Osteoconductive potential of mesoporous titania implant surfaces loaded with magnesium: An experimental study in the rabbit. Clin. Implant Dent. Relat. Res. 2015, 17, 1048-1059. [CrossRef] [PubMed]

201. Brown, A.; Zaky, S.; Ray, H., Jr.; Sfeir, C. Porous magnesium/PLGA composite scaffolds for enhanced bone regeneration following tooth extraction. Acta Biomater. 2015, 11, 543-553. [CrossRef] [PubMed]

202. Nabiyouni, M.; Brückner, T.; Zhou, H.; Gbureck, U.; Bhaduri, S.B. Magnesium-based Bioceramics in Orthopedic Applications. Acta Biomater. 2017. [CrossRef] [PubMed]

203. Raman, R.; Harandi, S.E. Resistance of Magnesium Alloys to Corrosion Fatigue for Biodegradable Implant Applications: Current Status and Challenges. Materials 2017, 10, 1316. [CrossRef] [PubMed]

204. Yang, J.; Koons, G.L.; Cheng, G.; Zhao, L.; Mikos, A.G.; Cui, F.-Z. A review on the exploitation of biodegradable magnesium-based composites for medical applications. Biomed. Mater. 2017. [CrossRef] [PubMed]

205. Pogorielov, M.; Husak, E.; Solodivnik, A.; Zhdanov, S. Magnesium-based biodegradable alloys: Degradation, application, and alloying elements. Int. Med. Appl. Sci. 2017, 9, 27-38. [CrossRef] [PubMed]

206. Yazdimamaghani, M.; Razavi, M.; Vashaee, D.; Moharamzadeh, K.; Boccaccini, A.R.; Tayebi, L. Porous magnesium-based scaffolds for Tissue Engineering. Mater. Sci. Eng. C 2017, 71, 1253-1266. [CrossRef] [PubMed]

207. Ibrahim, H.; Esfahani, S.N.; Poorganji, B.; Dean, D.; Elahinia, M. Resorbable bone fixation alloys, forming, and post-fabrication treatments. Mater. Sci. Eng. C 2017, 70, 870-888. [CrossRef] [PubMed]

208. Zhao, D.; Witte, F.; Lu, F.; Wang, J.; Li, J.; Qin, L. Current status on clinical applications of magnesium-based orthopaedic implants: A review from clinical translational perspective. Biomaterials 2017, 112, 287-302. [CrossRef] [PubMed]

209. Li, X.; Liu, X.; Wu, S.; Yeung, K.; Zheng, Y.; Chu, P.K. Design of magnesium alloys with controllable degradation for biomedical implants: From bulk to surface. Acta Biomater. 2016, 45, 2-30. [CrossRef] [PubMed]

210. Willbold, E.; Weizbauer, A.; Loos, A.; Seitz, J.M.; Angrisani, N.; Windhagen, H.; Reifenrath, J. Magnesium alloys: A stony pathway from intensive research to clinical reality. Different test methods and approval-related considerations. J. Biomed. Mater. Res. Part A 2017, 105, 329-347. [CrossRef] [PubMed]

211. Agarwal, S.; Curtin, J.; Duffy, B.; Jaiswal, S. Biodegradable magnesium alloys for orthopaedic applications: A review on corrosion, biocompatibility and surface modifications. Mater. Sci. Eng. C 2016, 68, 948-963. [CrossRef] [PubMed] 
212. Kuśnierczyk, K.; Basista, M. Recent advances in research on magnesium alloys and magnesium-calcium phosphate composites as biodegradable implant materials. J. Biomater. Appl. 2017, 31, 878-900. [CrossRef] [PubMed]

213. Saleh, M.M.; Touny, A.; Al-Omair, M.A.; Saleh, M. Biodegradable/biocompatible coated metal implants for orthopedic applications. Bio-Med. Mater. Eng. 2016, 27, 87-99. [CrossRef] [PubMed]

214. Heise, S.; Virtanen, S.; Boccaccini, A.R. Tackling Mg alloy corrosion by natural polymer coatings-A review. J. Biomed. Mater. Res. Part A 2016, 104, 2628-2641. [CrossRef] [PubMed]

215. Tian, P.; Liu, X. Surface modification of biodegradable magnesium and its alloys for biomedical applications. Regener. Biomater. 2015, 2, 135-151. [CrossRef] [PubMed]

216. Lu, J.; Wei, J.; Yan, Y.; Li, H.; Jia, J.; Wei, S.; Guo, H.; Xiao, T.; Liu, C. Preparation and preliminary cytocompatibility of magnesium doped apatite cement with degradability for bone regeneration. J. Mater. Sci. Mater. Med. 2011, 22, 607-615. [CrossRef] [PubMed]

217. He, L.; Zhang, X.; Liu, B.; Tian, Y.; Ma, W. Effect of magnesium ion on human osteoblast activity. Braz. J. Med. Biol. Res. 2016, 49. [CrossRef] [PubMed]

218. Leem, Y.H.; Lee, K.S.; Kim, J.H.; Seok, H.K.; Chang, J.S.; Lee, D.H. Magnesium ions facilitate integrin $\alpha$ 2-and $\alpha$ 3-mediated proliferation and enhance alkaline phosphatase expression and activity in hBMSCs. J. Tissue Eng. Regener. Med. 2016, 10. [CrossRef] [PubMed]

219. Yoshizawa, S.; Brown, A.; Barchowsky, A.; Sfeir, C. Magnesium ion stimulation of bone marrow stromal cells enhances osteogenic activity, simulating the effect of magnesium alloy degradation. Acta Biomater. 2014, 10, 2834-2842. [CrossRef] [PubMed]

220. Leidi, M.; Dellera, F.; Mariotti, M.; Maier, J.A. High magnesium inhibits human osteoblast differentiation in vitro. Magnes. Res. 2011, 24, 1-6. [CrossRef] [PubMed]

221. Zhang, L.; Yang, C.; Li, J.; Zhu, Y.; Zhang, X. High extracellular magnesium inhibits mineralized matrix deposition and modulates intracellular calcium signaling in human bone marrow-derived mesenchymal stem cells. Biochem. Biophys. Res. Commun. 2014, 450, 1390-1395. [CrossRef] [PubMed]

222. Li, Y.; Wang, J.; Yue, J.; Wang, Y.; Yang, C.; Cui, Q. High magnesium prevents matrix vesicle-mediated mineralization in human bone marrow-derived mesenchymal stem cells via mitochondrial pathway and autophagy. Cell Biol. Int. 2017. [CrossRef] [PubMed]

223. Tsao, Y.-T.; Shih, Y.-Y.; Liu, Y.-A.; Liu, Y.-S.; Lee, O.K. Knockdown of SLC41A1 magnesium transporter promotes mineralization and attenuates magnesium inhibition during osteogenesis of mesenchymal stromal cells. Stem Cell Res. Ther. 2017, 8, 39. [CrossRef] [PubMed]

224. Roy, M.; Nishimoto, S. Matrix Gla protein binding to hydroxyapatite is dependent on the ionic environment: Calcium enhances binding affinity but phosphate and magnesium decrease affinity. Bone 2002, 31, 296-302. [CrossRef]

225. O'Young, J.; Liao, Y.; Xiao, Y.; Jalkanen, J.; Lajoie, G.; Karttunen, M.; Goldberg, H.A.; Hunter, G.K. Matrix Gla protein inhibits ectopic calcification by a direct interaction with hydroxyapatite crystals. J. Am. Chem. Soc. 2011, 133, 18406-18412. [CrossRef] [PubMed]

226. Nakatani, S.; Mano, H.; Ryanghyok, I.; Shimizu, J.; Wada, M. Excess magnesium inhibits excess calcium-induced matrix-mineralization and production of matrix gla protein (MGP) by ATDC5 cells. Biochem. Biophys. Res. Commun. 2006, 348, 1157-1162. [CrossRef] [PubMed]

227. Ding, W. Opportunities and challenges for the biodegradable magnesium alloys as next-generation biomaterials. Regener. Biomater. 2016, 3, 79-86. [CrossRef] [PubMed]

228. Kim, J.-A.; Lim, J.; Naren, R.; Yun, H.-S.; Park, E.K. Effect of the biodegradation rate controlled by pore structures in magnesium phosphate ceramic scaffolds on bone tissue regeneration in vivo. Acta Biomater. 2016, 44, 155-167. [CrossRef] [PubMed]

229. Bornapour, M.; Celikin, M.; Cerruti, M.; Pekguleryuz, M. Magnesium implant alloy with low levels of strontium and calcium: The third element effect and phase selection improve bio-corrosion resistance and mechanical performance. Mater. Sci. Eng. C 2014, 35, 267-282. [CrossRef] [PubMed]

230. Weng, L.; Webster, T.J. Nanostructured magnesium increases bone cell density. Nanotechnology 2012, 23, 485105. [CrossRef] [PubMed]

231. Schramm, V.L. Manganese in Metabolism and Enzyme Function; Elsevier: Amsterdam, The Netherlands, 2012. 
232. Dormond, O.; Ponsonnet, L.; Hasmim, M.; Foletti, A.; Rüegg, C. Manganese-induced integrin affinity maturation promotes recruitment of $\alpha \mathrm{V} \beta 3$ integrin to focal adhesions in endothelial cells: Evidence for a role of phosphatidylinositol 3-kinase and Src. Thromb. Haemost. 2004, 91, 151-161. [CrossRef] [PubMed]

233. Mould, A.P.; Akiyama, S.K.; Humphries, M.J. Regulation of Integrin $\alpha 5 \beta 1$-Fibronectin Interactions by Divalent Cations Evidence for Distinct Classes of Binding Sites for $\mathrm{Mn}^{2+}, \mathrm{Mg}^{2+}$, and $\mathrm{Ca}^{2+}$. J. Biol. Chem. 1995, 270, 26270-26277. [CrossRef] [PubMed]

234. Lüthen, F.; Bulnheim, U.; Müller, P.D.; Rychly, J.; Jesswein, H.; Nebe, J.B. Influence of manganese ions on cellular behavior of human osteoblasts in vitro. Biomol. Eng. 2007, 24, 531-536. [CrossRef] [PubMed]

235. Pabbruwe, M.B.; Standard, O.C.; Sorrell, C.C.; Howlett, C.R. Bone formation within alumina tubes: Effect of calcium, manganese, and chromium dopants. Biomaterials 2004, 25, 4901-4910. [CrossRef] [PubMed]

236. Paglia, D.N.; Wey, A.; Park, A.G.; Breitbart, E.A.; Mehta, S.K.; Bogden, J.D.; Kemp, F.W.; Benevenia, J.; O'connor, J.P.; Lin, S.S. The effects of local vanadium treatment on angiogenesis and chondrogenesis during fracture healing. J. Orthop. Res. 2012, 30, 1971-1978. [CrossRef] [PubMed]

237. Subasinghe, S.; Greenbaum, A.L.; McLean, P. The insulin-mimetic action of $\mathrm{Mn}^{2+}$ : Involvement of cyclic nucleotides and insulin in the regulation of hepatic hexokinase and glucokinase. Biochem. Med. 1985, 34, 83-92. [CrossRef]

238. Hreha, J.; Wey, A.; Cunningham, C.; Krell, E.S.; Brietbart, E.A.; Paglia, D.N.; Montemurro, N.J.; Nguyen, D.A.; Lee, Y.J.; Komlos, D.; et al. Local manganese chloride treatment accelerates fracture healing in a rat model. J. Orthop. Res. 2015, 33, 122-130. [CrossRef] [PubMed]

239. Russell, A.; Hugo, W. 7 antimicrobial activity and action of silver. In Progress in Medicinal Chemistry; Elsevier: Amsterdam, The Netherlands, 1994; Volume 31, pp. 351-370. [CrossRef]

240. Jeanmonod, P.; Laschke, M.W.; Gola, N.; von Heesen, M.; Glanemann, M.; Dold, S.; Menger, M.D.; Moussavian, M.R. Silver acetate coating promotes early vascularization of Dacron vascular grafts without inducing host tissue inflammation. J. Vasc. Surg. 2013, 58, 1637-1643. [CrossRef] [PubMed]

241. Rigo, C.; Ferroni, L.; Tocco, I.; Roman, M.; Munivrana, I.; Gardin, C.; Cairns, W.R.; Vindigni, V.; Azzena, B.; Barbante, C. Active silver nanoparticles for wound healing. Int. J. Mol. Sci. 2013, 14, 4817-4840. [CrossRef] [PubMed]

242. Hebeish, A.; El-Rafie, M.; El-Sheikh, M.; Seleem, A.A.; El-Naggar, M.E. Antimicrobial wound dressing and anti-inflammatory efficacy of silver nanoparticles. Int. J. Biol. Macromol. 2014, 65, 509-515. [CrossRef] [PubMed]

243. Tian, J.; Wong, K.K.; Ho, C.M.; Lok, C.N.; Yu, W.Y.; Che, C.M.; Chiu, J.F.; Tam, P.K. Topical delivery of silver nanoparticles promotes wound healing. ChemMedChem 2007, 2, 129-136. [CrossRef] [PubMed]

244. Qin, H.; Zhu, C.; An, Z.; Jiang, Y.; Zhao, Y.; Wang, J.; Liu, X.; Hui, B.; Zhang, X.; Wang, Y. Silver nanoparticles promote osteogenic differentiation of human urine-derived stem cells at noncytotoxic concentrations. Int. J. Nanomed. 2014, 9, 2469. [CrossRef] [PubMed]

245. Mahmood, M.; Li, Z.; Casciano, D.; Khodakovskaya, M.V.; Chen, T.; Karmakar, A.; Dervishi, E.; Xu, Y.; Mustafa, T.; Watanabe, F.; et al. Nanostructural materials increase mineralization in bone cells and affect gene expression through miRNA regulation. J. Cell. Mol. Med. 2011, 15, 2297-2306. [CrossRef] [PubMed]

246. Qing, T.; Mahmood, M.; Zheng, Y.; Biris, A.S.; Shi, L.; Casciano, D.A. A genomic characterization of the influence of silver nanoparticles on bone differentiation in MC3T3-E1 cells. J. Appl. Toxicol. 2018, 38, 172-179. [CrossRef] [PubMed]

247. Kwan, K.H.; Liu, X.; To, M.K.; Yeung, K.W.; Ho, C.-M.; Wong, K.K. Modulation of collagen alignment by silver nanoparticles results in better mechanical properties in wound healing. Nanomed. Nanotechnol. Biol. Med. 2011, 7, 497-504. [CrossRef] [PubMed]

248. Liu, X.; Lee, P.Y.; Ho, C.M.; Lui, V.C.; Chen, Y.; Che, C.M.; Tam, P.K.; Wong, K.K. Silver nanoparticles mediate differential responses in keratinocytes and fibroblasts during skin wound healing. ChemMedChem 2010, 5, 468-475. [CrossRef] [PubMed]

249. Zhang, R.; Lee, P.; Lui, V.C.; Chen, Y.; Liu, X.; Lok, C.N.; To, M.; Yeung, K.W.; Wong, K.K. Silver nanoparticles promote osteogenesis of mesenchymal stem cells and improve bone fracture healing in osteogenesis mechanism mouse model. Nanomed. Nanotechnol. Biol. Med. 2015, 11, 1949-1959. [CrossRef] [PubMed]

250. Yang, F.; Yang, D.; Tu, J.; Zheng, Q.; Cai, L.; Wang, L. Strontium enhances osteogenic differentiation of mesenchymal stem cells and in vivo bone formation by activating Wnt/catenin signaling. Stem Cells 2011, 29, 981-991. [CrossRef] [PubMed] 
251. Reginster, J.-Y.; Seeman, E.; De Vernejoul, M.; Adami, S.; Compston, J.; Phenekos, C.; Devogelaer, J.-P.; Curiel, M.D.; Sawicki, A.; Goemaere, S. Strontium ranelate reduces the risk of nonvertebral fractures in postmenopausal women with osteoporosis: Treatment of Peripheral Osteoporosis (TROPOS) study. J. Clin. Endocrinol. Metab. 2005, 90, 2816-2822. [CrossRef] [PubMed]

252. Saidak, Z.; Marie, P.J. Strontium signaling: Molecular mechanisms and therapeutic implications in osteoporosis. Pharmacol. Ther. 2012, 136, 216-226. [CrossRef] [PubMed]

253. Marie, P.J. Strontium ranelate: A dual mode of action rebalancing bone turnover in favour of bone formation. Curr. Opin. Rheumatol. 2006, 18, S11-S15. [CrossRef] [PubMed]

254. Ammann, P. Strontium ranelate: A novel mode of action leading to renewed bone quality. Osteoporos. Int. 2005, 16, S11-S15. [CrossRef] [PubMed]

255. Bonnelye, E.; Chabadel, A.; Saltel, F.; Jurdic, P. Dual effect of strontium ranelate: Stimulation of osteoblast differentiation and inhibition of osteoclast formation and resorption in vitro. Bone 2008, 42, 129-138. [CrossRef] [PubMed]

256. Chattopadhyay, N.; Quinn, S.J.; Kifor, O.; Ye, C.; Brown, E.M. The calcium-sensing receptor (CaR) is involved in strontium ranelate-induced osteoblast proliferation. Biochem. Pharmacol. 2007, 74, 438-447. [CrossRef] [PubMed]

257. Hurtel-Lemaire, A.S.; Mentaverri, R.; Caudrillier, A.; Cournarie, F.; Wattel, A.; Kamel, S.; Terwilliger, E.F.; Brown, E.M.; Brazier, M. The calcium-sensing receptor is involved in strontium ranelate-induced osteoclast apoptosis new insights into the associated signaling pathways. J. Biol. Chem. 2009, 284, 575-584. [CrossRef] [PubMed]

258. Takaoka, S.; Yamaguchi, T.; Yano, S.; Yamauchi, M.; Sugimoto, T. The Calcium-sensing Receptor (CaR) is involved in strontium ranelate-induced osteoblast differentiation and mineralization. Horm. Metab. Res. 2010, 42, 627-631. [CrossRef] [PubMed]

259. Barbara, A.; Delannoy, P.; Denis, B.; Marie, P. Normal matrix mineralization induced by strontium ranelate in MC3T3-E1 osteogenic cells. Metab.-Clin. Exp. 2004, 53, 532-537. [CrossRef] [PubMed]

260. Rybchyn, M.S.; Slater, M.; Conigrave, A.D.; Mason, R.S. An Akt-dependent increase in canonical Wnt signaling and a decrease in sclerostin protein levels are involved in strontium ranelate-induced osteogenic effects in human osteoblasts. J. Biol. Chem. 2011, 286, 23771-23779. [CrossRef] [PubMed]

261. Brennan, T.C.; Rybchyn, M.S.; Green, W.; Atwa, S.; Conigrave, A.D.; Mason, R.S. Osteoblasts play key roles in the mechanisms of action of strontium ranelate. Br. J. Pharmacol. 2009, 157, 1291-1300. [CrossRef] [PubMed]

262. Schumacher, M.; Wagner, A.; Kokesch-Himmelreich, J.; Bernhardt, A.; Rohnke, M.; Wenisch, S.; Gelinsky, M. Strontium substitution in apatitic CaP cements effectively attenuates osteoclastic resorption but does not inhibit osteoclastogenesis. Acta Biomater. 2016, 37, 184-194. [CrossRef] [PubMed]

263. Atteritano, M.; Catalano, A.; Santoro, D.; Lasco, A.; Benvenga, S. Effects of strontium ranelate on markers of cardiovascular risk in postmenopausal osteoporotic women. Endocrine 2016, 53, 305-312. [CrossRef] [PubMed]

264. Li, Y.; Li, Q.; Zhu, S.; Luo, E.; Li, J.; Feng, G.; Liao, Y.; Hu, J. The effect of strontium-substituted hydroxyapatite coating on implant fixation in ovariectomized rats. Biomaterials 2010, 31, 9006-9014. [CrossRef] [PubMed]

265. Forsgren, J.; Engqvist, H. A novel method for local administration of strontium from implant surfaces. J. Mater. Sci. Mater. Med. 2010, 21, 1605-1609. [CrossRef] [PubMed]

266. Xin, Y.; Jiang, J.; Huo, K.; Hu, T.; Chu, P.K. Bioactive $\mathrm{SrTiO}_{3}$ nanotube arrays: Strontium delivery platform on Ti-based osteoporotic bone implants. ACS Nano 2009, 3, 3228-3234. [CrossRef] [PubMed]

267. Li, Y.; Leong, J.; Lu, W.; Luk, K.; Cheung, K.; Chiu, K.; Chow, S. A novel injectable bioactive bone cement for spinal surgery: A developmental and preclinical study. J. Biomed. Mater. Res. Part A 2000, 52, 164-170. [CrossRef]

268. Alkhraisat, M.H.; Moseke, C.; Blanco, L.; Barralet, J.E.; Lopez-Carbacos, E.; Gbureck, U. Strontium modified biocements with zero order release kinetics. Biomaterials 2008, 29, 4691-4697. [CrossRef] [PubMed]

269. Dagang, G.; Kewei, X.; Yong, H. The influence of Sr doses on the in vitro biocompatibility and in vivo degradability of single-phase Sr-incorporated HAP cement. J. Biomed. Mater. Res. Part A 2008, 86, 947-958. [CrossRef] [PubMed]

270. Tadier, S.; Bareille, R.; Siadous, R.; Marsan, O.; Charvillat, C.; Cazalbou, S.; Amédée, J.; Rey, C.; Combes, C. Strontium-loaded mineral bone cements as sustained release systems: Compositions, release properties, 
and effects on human osteoprogenitor cells. J. Biomed. Mater. Res. Part B Appl. Biomater. 2012, 100, 378-390. [CrossRef] [PubMed]

271. Romieu, G.; Garric, X.; Munier, S.; Vert, M.; Boudeville, P. Calcium-strontium mixed phosphate as novel injectable and radio-opaque hydraulic cement. Acta Biomater. 2010, 6, 3208-3215. [CrossRef] [PubMed]

272. Pina, S.; Torres, P.; Goetz-Neunhoeffer, F.; Neubauer, J.; Ferreira, J. Newly developed Sr-substituted $\alpha$-TCP bone cements. Acta Biomater. 2010, 6, 928-935. [CrossRef] [PubMed]

273. Zhang, W.; Shen, Y.; Pan, H.; Lin, K.; Liu, X.; Darvell, B.W.; Lu, W.W.; Chang, J.; Deng, L.; Wang, D.; et al. Effects of strontium in modified biomaterials. Acta Biomater. 2011, 7, 800-808. [CrossRef] [PubMed]

274. Ginebra, M.-P.; Canal, C.; Espanol, M.; Pastorino, D.; Montufar, E.B. Calcium phosphate cements as drug delivery materials. Adv. Drug Deliv. Rev. 2012, 64, 1090-1110. [CrossRef] [PubMed]

275. Querido, W.; Rossi, A.L.; Farina, M. The effects of strontium on bone mineral: A review on current knowledge and microanalytical approaches. Micron 2016, 80, 122-134. [CrossRef] [PubMed]

276. Dahl, S.; Allain, P.; Marie, P.; Mauras, Y.; Boivin, G.; Ammann, P.; Tsouderos, Y.; Delmas, P.; Christiansen, C. Incorporation and distribution of strontium in bone. Bone 2001, 28, 446-453. [CrossRef]

277. Poucheret, P.; Verma, S.; Grynpas, M.D.; McNeill, J.H. Vanadium and diabetes. Mol. Cell. Biochem. 1998, 188, 73-80. [CrossRef] [PubMed]

278. Nobes, C.D.; Hawkins, P.; Stephens, L.; Hall, A. Activation of the small GTP-binding proteins rho and rac by growth factor receptors. J. Cell Sci. 1995, 108, 225-233. [PubMed]

279. Barrio, D.; Etcheverry, S. Vanadium and bone development: Putative signaling pathways. Can. J. Physiol. Pharmacol. 2006, 84, 677-686. [CrossRef] [PubMed]

280. Cortizo, A.M.; Etcheverry, S.B. Vanadium derivatives act as growth factor-Mimetic compounds upon differentiation and proliferation of osteoblast-like UMR106 cells. Mol. Cell. Biochem. 1995, 145, 97-102. [CrossRef] [PubMed]

281. Gandhi, A.; Beam, H.A.; O'Connor, J.P.; Parsons, J.R.; Lin, S.S. The effects of local insulin delivery on diabetic fracture healing. Bone 2005, 37, 482-490. [CrossRef] [PubMed]

282. Dedania, J.; Borzio, R.; Paglia, D.; Breitbart, E.A.; Mitchell, A.; Vaidya, S.; Wey, A.; Mehta, S.; Benevenia, J.; O'connor, J.P.; et al. Role of local insulin augmentation upon allograft incorporation in a rat femoral defect model. J. Orthop. Res. 2011, 29, 92-99. [CrossRef] [PubMed]

283. Cortizo, A.M.; Ruderman, G.; Mazzini, F.N.; Molinuevo, M.S.; Mogilner, I.G. Novel vanadium-loaded ordered collagen scaffold promotes osteochondral differentiation of bone marrow progenitor cells. Int. J. Biomater. 2016, 2016. [CrossRef] [PubMed]

284. Jarrell, J.D.; Dolly, B.; Morgan, J.R. Controlled release of vanadium from titanium oxide coatings for improved integration of soft tissue implants. J. Biomed. Mater. Res. Part A 2009, 90, 272-281. [CrossRef] [PubMed]

285. Rink, L. Zinc and the immune system. Proc. Nutr. Soc. 2000, 59, 541-552. [CrossRef] [PubMed]

286. MacDonald, R.S. The role of zinc in growth and cell proliferation. J. Nutr. 2000, 130, 1500S-1508S. [CrossRef] [PubMed]

287. Yamaguchi, M. Role of zinc in bone formation and bone resorption. J. Trace Elem. Exp. Med. 1998, 11, 119-135. [CrossRef]

288. Zhu, D.; Su, Y.; Young, M.L.; Ma, J.; Zheng, Y.; Tang, L. Biological responses and mechanisms of human bone marrow mesenchymal stem cells to Zn and Mg biomaterials. ACS Appl. Mater. Interfaces 2017, 9, 27453-27461. [CrossRef] [PubMed]

289. Ma, J.; Zhao, N.; Zhu, D. Bioabsorbable zinc ion induced biphasic cellular responses in vascular smooth muscle cells. Sci. Rep. 2016, 6, 26661. [CrossRef] [PubMed]

290. Qiao, Y.; Zhang, W.; Tian, P.; Meng, F.; Zhu, H.; Jiang, X.; Liu, X.; Chu, P.K. Stimulation of bone growth following zinc incorporation into biomaterials. Biomaterials 2014, 35, 6882-6897. [CrossRef] [PubMed]

291. Nagata, M.; Lönnerdal, B. Role of zinc in cellular zinc trafficking and mineralization in a murine osteoblast-like cell line. J. Nutr. Biochem. 2011, 22, 172-178. [CrossRef] [PubMed]

292. Yamaguchi, M.; Weitzmann, M.N. Zinc stimulates osteoblastogenesis and suppresses osteoclastogenesis by antagonizing NF-kB activation. Mol. Cell. Biochem. 2011, 355, 179. [CrossRef] [PubMed]

293. Seo, H.-J.; Cho, Y.-E.; Kim, T.; Shin, H.-I.; Kwun, I.-S. Zinc may increase bone formation through stimulating cell proliferation, alkaline phosphatase activity and collagen synthesis in osteoblastic MC3T3-E1 cells. Nutr. Res. Pract. 2010, 4, 356-361. [CrossRef] [PubMed] 
294. Chou, A.H.; LeGeros, R.Z.; Chen, Z.; Li, Y. Antibacterial effect of zinc phosphate mineralized guided bone regeneration membranes. Implant Dent. 2007, 16, 89-100. [CrossRef] [PubMed]

295. Chou, J.; Komuro, M.; Hao, J.; Kuroda, S.; Hattori, Y.; Ben-Nissan, B.; Milthorpe, B.; Otsuka, M. Bioresorbable zinc hydroxyapatite guided bone regeneration membrane for bone regeneration. Clin. Oral Implant. Res. 2016, 27, 354-360. [CrossRef] [PubMed]

296. Chen, J.; Zhang, X.; Cai, H.; Chen, Z.; Wang, T.; Jia, L.; Wang, J.; Wan, Q.; Pei, X. Osteogenic activity and antibacterial effect of zinc oxide/carboxylated graphene oxide nanocomposites: Preparation and in vitro evaluation. Colloids Surf. B Biointerfaces 2016, 147, 397-407. [CrossRef] [PubMed]

297. Luo, X.; Barbieri, D.; Davison, N.; Yan, Y.; de Bruijn, J.D.; Yuan, H. Zinc in calcium phosphate mediates bone induction: In vitro and in vivo model. Acta Biomater. 2014, 10, 477-485. [CrossRef] [PubMed]

298. Yu, J.; Xu, L.; Li, K.; Xie, N.; Xi, Y.; Wang, Y.; Zheng, X.; Chen, X.; Wang, M.; Ye, X. Zinc-modified calcium silicate coatings promote osteogenic differentiation through TGF- $\beta /$ Smad pathway and osseointegration in osteopenic rabbits. Sci. Rep. 2017, 7, 3440. [CrossRef] [PubMed]

299. Webster, T.J.; Ergun, C.; Doremus, R.H.; Bizios, R. Hydroxylapatite with substituted magnesium, zinc, cadmium, and yttrium. II. Mechanisms of osteoblast adhesion. J. Biomed. Mater. Res. Part A 2002, 59, 312-317. [CrossRef] [PubMed]

300. Manivasagam, G.; Dhinasekaran, D.; Rajamanickam, A. Biomedical Implants: Corrosion and its Prevention-A Review. Recent Pat. Corros. Sci. 2010, 2, 40-54. [CrossRef]

301. Fleck, C.; Eifler, D. Corrosion, fatigue and corrosion fatigue behaviour of metal implant materials, especially titanium alloys. Int. J. Fatigue 2010, 32, 929-935. [CrossRef]

302. Wang, J.Y.; Wicklund, B.H.; Gustilo, R.B.; Tsukayama, D.T. Titanium, chromium and cobalt ions modulate the release of bone-associated cytokines by human monocytes/macrophages in vitro. Biomaterials 1996, 17, 2233-2240. [CrossRef]

303. Woodman, J.; Jacobs, J.; Galante, J.; Urban, R. Metal ion release from titanium-based prosthetic segmental replacements of long bones in baboons: A long-term study. J. Orthop. Res. 1983, 1, 421-430. [CrossRef] [PubMed] 